\title{
OBJECTIVE CONJUGATION AND MEDIALISATION
}

\author{
FERENC HAVAS
}

\begin{abstract}
This paper is concerned with the origins and the function of the objective verbal conjugation especially in Hungarian but with an eye to general typology and Uralic. Previous attempts at solving problems associated with it are given a critical survey. The author argues that since objective conjugation is neither specific to Hungarian nor to its relatives, whether close or distant, but is found in various language families and language types all over the world, one should seek explanations in universal tendencies rather than giving ad hoc accounts. The universal tendency of medialisation is pointed out here - especially in the first and second persons of the paradigm - , which differentiated what is now called the (unmarked) general or indefinite conjugation from the original unitary conjugation. It is here proposed that what now functions as the objective conjugation results historically from a reinterpretation of the original paradigm as in contrast with the medial (then general) paradigm. This explains the curious fact that although the objective paradigm is now seen as the new marked member of the opposition, it is this paradigm that preserves the personal endings going back to the ancestral pronouns. The author also argues that the emergence of an objective conjugation in those Uralic languages that have one represents independent developments, though the preconditions for its evolution may have been there in Proto-Uralic in the form of object syntagms.
\end{abstract}

1. The development of finite or person-marked verb forms is, in all cases, a textbook example of grammaticalisation. Even if it involves only the attachment of personal pronouns to verbs, which is the most archaic and, in all likelihood the most general, way leading to a verbal paradigm, the fact that in this process the pronoun loses its autonomous syntactic function (e.g., that of subject) and turns instead into the exponent of a grammatical category within the verb phrase means that it assumes a function that it was originally not meant to fulfil - at least in that way. This is even clearer when the emerging person-marker ${ }^{1}$ originally had not had that function. Perhaps there is not a single language in which at least

${ }^{1}$ The term person-marker here does not refer to suffixes only, as it exclusively does in the Hungarian grammatical tradition, but to any morpheme that marks the person of the subject or some compulsory complement on the verb itself. It may be realised as a prefix, an infix, a suffix or a clitic. 
one series of person markers does not originate from personal pronouns $(\mathrm{PPs})$, but if a language possesses several series of person-markers (Vxes), there is a good chance that some of these do not derive from PPs. A Vx that does not derive from a PP is likely to have undergone several distinct grammaticalisation processes.

This paper discusses that type of verbal conjugations which are called - if not always correctly - objective systems. It is obvious that this belongs to the domain of grammaticalisation, since if objective paradigms did not always exist, as they clearly did not, they must have come about through processes of grammaticalisation. We shall focus on the relevant paths of development in the Hungarian verbal system (and will propose a theory of our own, like so many others have done before), but in doing so we shall relate our findings to two broader fields of research: Uralic linguistics and typology. By the latter we simply mean the non-genetic, non-areal, but purely structural comparison of languages. It does not require much explanation that objective verbal paradigms are not unique to either Hungarian or its closer or more distant relatives but can be found in totally unrelated and typologically dissimilar languages/families. It thus seems reasonable to step back and take a broader look.

2. In order to arrive at a reliable survey of the world's languages in terms of the existence and the properties of an objective conjugation we first have to give a definition of what we are actually looking for. This is all the more important since the phenomena we mean or should mean by the term "objective conjugation" are, in fact, highly disparate and differ along a number of dimensions - this is the reason for the proliferation of the relevant terminology in the literature.

We suggest, first of all, "object-dependent verbal conjugation" as a general term to be used in discussing these phenomena. This does not refer to a specific verbal paradigm but simply to the fact that a given language possesses such a distinction. What is thereby distinguished is generally an object-oriented vs. a non-object-oriented verbal conjugation. A language possesses object-dependent verbal conjugation if it fulfils two criteria:

2.1. There are finite verbs in the language (i.e., there is a verbal conjugation). 
2.2. The orientation of the verb towards the object is expressed by some dedicated morphological element or special formation. This can be realised in two ways:

2.2.1. Formatives outside person-marking, such as infixation (e.g., in Vogul), thematic vowel differences (e.g., in Ostyak), clitic elements (French and Italian etc. unstressed pronouns probably belong here), in some cases derivational morphemes (e.g., in Indonesian) or some form of steminternal inflection on the verb etc.

2.2.2. Within person marking, in which case there are at least two sets of Vx-es and the choice between the two is determined by the object in some way.

3. Object-dependent verbal conjugation, defined as above, may fall into a variety of patterns. Its types can be classified according to three independent parameters: function, morphology and extension.

3.1. Functionally one may distinguish between extensive and intensive object-dependence.

3.1.1. A pattern is called extensive if the conjugations of transitive vs. intransitive verbs differ consistently. The traditional Hungarian terms alanyi 'subjective' and tárgyas 'objective' should, in theory, be applied to such languages only. In principle, extensive object-dependence can also be of two kinds:

3.1.1.1. In a lexically rigid system transitive verbs are realised as such in all cases, even if in a particular instance they occur without an object as in semantically medial use. In such a language a verb like write would be conjugated transitively even in a sentence like this pen writes well. Transitive and intransitive conjugations in these languages (but only in these languages) mean separate verb classes ('conjugations' in the traditional sense of the word). Lak and Kashmiri appear to belong to this type, and a set of North-West Iranian languages appear to belong here too, such as Gurani, Lasgerdi, Meimei etc., as far as their past tenses are concerned.

3.1.1.2. In a structure-dependent system transitive verbs are conjugated as such only when the sentence actually has an object or, depending on the language, only when the sentence actually does not have an object. In such languages, two different verb conjugations would appear in he is eating vs. he is eating bread. 
3.1.2. Intensive object-dependence means that transitive verbs are conjugated in a specific way only when accompanied by some salient type of object, otherwise their forms coincide with those of (some type of) intransitive verbs. In a general sense this may be referred to as a distinction between determinate vs. indeterminate verbal conjugation, and its subtypes are defined by what salience of object means in a given system.

3.1.2.1. Definiteness of the object (definite vs. general conjugation). Hungarian is a case in point (if one disregards the suffix -lak/-lek ' 1 sg subj. 2 sg obj.').

3.1.2.2. Specific number and person of the object. Here belong all languages where finite verbs forms are selected in accordance with the combination of subject and object, e.g., Mordvin. (The intransitive category may itself be composite, as in the Northen Samoyedic languages, where it includes a subjective and a medial conjugation.) The prominence hierarchy can be regarded as a subtype of this category; it means that the objective conjugation is used as a function of the relation between the number and person specifications of the subject compared to those of the object. Chukchee, Koryak and Kamchadal are languages like that. Interestingly, if the Hungarian suffix -lak/-lek is interpreted as belonging to the objective conjugation, this language can also be assigned to this class (more precisely, to this class as well). ${ }^{2}$

3.1.2.3. The object is salient in some other way. This class is actually a collection of various patterns, which further analysis may well show to constitute disparate subclasses. Such "other" triggers of objective conjugation include position next to a focussed verb (Yukaghir, perhaps

\footnotetext{
${ }^{2}$ On this see É. Kiss (2003). Classifying the suffix -lak/-lek as objective currently contravenes the orthodoxy of Hungarian descriptive grammar. We think that semantic considerations (independently of É. Kiss's arguments, which are based on Comrie 1980) as well as the comparative evidence of Finno-Ugric-e.g., Mordvin, which shows fundamentally the same pattern - point unequivocally to the suffix being object-oriented. Theoretically, it cannot be otherwise: its choice is determined solely by second person objects, as opposed to other Vx1sg's. Claims to the opposite err in that they equate 'objective' with 'having a definite object', which cannot be interpreted with reference to first and second persons, at least in Hungarian (or, if it can, engem 'I-acc' and téged 'you.sg-acc' certainly qualify as definite).
} 
Nenets, partly Ob-Ugric) ${ }^{3}$ the number of the object independently of its person (Ob-Ugric) or the semantic class of the object (Avar), etc.

3.1.2.3.1. It may be regarded as a subtype of objects "salient in some other way" when the formation of the transitive construction depends not on structural but on use-related, contextual factors like, for instance, the speaker's ad hoc semantic intentions (as in Tundra Nenets). ${ }^{4}$

3.1.2.3.2. Several factors may combine in a given language (in Hungarian, for instance, both the definiteness and the person of the object play a role in the choice of the conjugation).

3.2. Apart from function, object-dependent verbal conjugation can be classified morphologically as well. For simplicity, let us take a closer look only at the person-marking pattern. ${ }^{5}$ We can distinguish two major types:

3.2.1. Analytic: person-markers on verbs are - or demonstrably werecomposite, i.e., separate portions of them refer(red) to the subject and the object, respectively. Mordvin is an instance and so is the Hungarian suffix -lak/-lek if its -l- element is etymologically identical to the Vx of játszo-l 'you play'. 6

3.2.2. Synthetic: the person-markers are not composite at all, or do not arise as a combination of different Vx-es, thus the exponent of the subject and the exponent of the object cannot be separated in them either synchronically or diachronically. This is clearly the case in Hungarian, especially in the singular (láto-m 'I see it' etc.).

3.3. The third criterion relates not to what the object-dependent verbal conjugation is like in itself but to its extension, i.e., whether the distinction between object-oriented and non-object-oriented conjugation per-

\footnotetext{
${ }^{3}$ Whether Samoyedic and Ob-Ugric belong here is, in fact, less and less certain. Körtvély (2003b) unequivocally proves the opposite for Tundra Nenets, and personal communication with several experts seems to indicate that Ob-Ugric was also erroneously analysed as belonging to this class.

${ }^{4}$ See Körtvély (2003b).

${ }^{5}$ It may well be the case that this distinction holds for other patterns too, but since this question is irrelevant for our present query, the historical study of the Hungarian objective conjugation, we shall disregard it.

${ }^{6}$ In fact, the $-l$ - of -lak/-lek certainly refers descriptively to the object even if it is not of a $\mathrm{Vx}$ origin, since the $-k$ element definitely refers to the 1 sg subject only. In that case, however, the suffix -lak/-lek belongs rather to 3.1.2.3.2.
} 
vades the entire system of transitive verbs and the constructions they are parts of or whether it is incomplete in some respect. Two different kinds of incompleteness can be observed which, for simplicity, will again be referred to as extensive vs. intensive incompleteness.

3.3.1. Extensive incompleteness means that a well-defined subset of transitive verbs does not take part in object-dependent contrasts. Such is the case of Tundra Nenets, where a certain group of transitive verbs displays rigid, but the larger part intensively object-dependent, behaviour. ${ }^{7}$

3.3.2. Intensive incompleteness means that object-dependent verbal conjugation is confined to certain numbers, persons, tenses, moods etc. in a given language. In a set of Iranian languages, for instance, objective conjugation exists only in the past tense.

3.3.3. While not a separate type in its own right, one may mention unsystematic incompleteness here, which means a combination of $\mathbf{3 . 3 . 1}$ and 3.3.2 type criteria (only certain verbs display object-dependent features in only certain grammatical categories), or a state of the system where the majority patterns do not hold for certain specific items defined by a variety of criteria - lexical or grammatical remnant forms. This is an extremely frequent phenomenon. Conspicuous examples can be taken from Hungarian, where the distinction is neutralised in the 1sg present indicative forms of 'pristine $i k$-verbs' (eszem 'I eat'), in the 1sg past indicative of all transitive verbs (láttam 'I saw') as well as in $1 \mathrm{pl}$ and $2 \mathrm{pl}$ conditional forms (látnánk, látnátok 'we/you would see'). ${ }^{8}$

4. Despite all these differences, the languages that display object-dependent verbal conjugation constitute a unitary class as opposed to languages that lack finite verbs or have only one conjugation - at least from the point of view of the object.

4.1. The following languages, classified according to families for the sake of exposition, possess object-dependent verbal conjugation (typographical distinctions will be discussed later):

\footnotetext{
${ }^{7}$ Körtvély (2003a, 97).

${ }^{8}$ It is, of course, true that in the first and last two of these four forms the neutralisation of the distinction only holds in a narrow synchronic sense. In $1 \mathrm{pl}$ conditional látnánk used to be an indefinite form in contrast to látnók, and for $i k$-verbs indefinite forms like eszek are quite general in non-standard varieties, in which then eszem is reclassified as definite.
} 
(1) Uralic: Hungarian, Vogul, Ostyak, Mordvin, Enets, Nenets, Nganasan, Selkup. Caucasian: (Kartvelian:) Georgian, Mingrelian, Chan, (Nahi-Daghestanian:) Lak.

Paleo-Siberian: Chukchee, Koryak, Kerek, Yug and Ket, Kot, Yuit, Naukani, Itelmen, Greenlandic.

Indo-European: (Dardic:) Kashmiri, Pashai, (South-West Iranian:) Middle Persian, (North-West Iranian:) Parthian, Beluj, Gurani, Lasgerdi, Biyabuneki, Aftari, Meimei, Jawshakani, Khunsari, Vonishuni, Käviri dialects, Sivandi, (East Iranian:) Yida-Munji, Jaghnobi, Ossetic.

Australian: Wunambal.

American Indian: Alaskan Yupik, Cree.

Sino-Tibetan: Dyarang.

African: Swaheli (and other Bantu languages).

This is, of course, not meant to be an exhaustive survey of the world's languages - that would be beyond our subjective as well as objective capacities - , but it will be enough to demonstrate that object-dependent verbal conjugation as a phenomenon is independent of the genetic relations of languages. Apart from a few specific cases, those showing object-dependent verbal conjugation belong to entirely different families, and, on the other hand, while this may not be clear from the above, but is still warranted by our general knowledge of language families, closely related languages may well differ from each other in this respect. Furthermore, if the various subtypes of object-dependent verbal conjugation are taken into account, closely related languages showing this feature may be representatives of different subtypes, as are Hungarian, Ob-Ugric and Mordvin, which belong to three different subtypes (more precisely, three different principles of transitivity) within the set of those Finno-Ugric languages that actually display object-dependent verbal conjugation. The same is seen if we try to classify these languages typologically. The existence of verb forms as such is, of course, a morphological prerequisite, thus strictly isolating languages are out of question, but agglutinating, fusional and incorporating types are all represented within the above list. Syntactically these languages are partly nominative, partly ergative, ${ }^{9}$ but in the majority of languages showing the same two syntactic patterns ob-

${ }^{9} \mathrm{I}$ have not been able to survey active languages from this respect, though the question could be investigated if we substituted patients for objects. Assuming transitivity in ergative languages also involves taking the absolutive next to a transitive verb to be an object. 
ject-dependent verbal conjugation does not exist. If, finally, we locate these languages geographically, even this small sample will make it clear that the occurrence of object-dependent verbal conjugation is independent not only of genetic and typological but also of areal traits.

4.2. Since the ultimate goal of our survey is a comparison with Hungarian, we have indicated in the list the extent to which these languages can be regarded as similar to Hungarian (strictly in terms of what the objective conjugation is like). Languages in italics display object-dependence mainly in the person-markers, whereas in the languages shown in bold the Vx-es in question are synthetic at least in part. No genetic, typological or areal correspondences (of a non-coincidental kind) are found here, either. Looking at the Uralic languages, including those that have no object-dependent verbal conjugation as well as those that have it, and which, as seen above, belong to three different subtypes, one may well wonder whether the Hungarian objective conjugation is of Uralic provenance. This is all the more so given that the following unrelated - languages show a system very similar to that of Hungarian:

4.2.1. Aftari (North-West Iranian language, spoken in the Semnan-region, shares this feature with closely related dialects Lasgerdi and Biyabuneki). ${ }^{10}$ Here belongs its past declension, of which the singular objective endings are synthetic:

$\begin{array}{ll}\text { Intransitive } & \text { verbs } \\ \mathrm{Sg} & \mathrm{Pl} \\ -i & -i m \\ -a & -i n \\ -a & -e n\end{array}$

\begin{tabular}{ll}
\multicolumn{2}{c}{ Transitive verbs } \\
$\mathrm{Sg}$ & $\mathrm{Pl}$ \\
$-(u) m$ & - mun \\
$-(u / o) t$ & - tun \\
$-(o) \check{s}$ & $-\check{s} u n$
\end{tabular}

This being an Indo-European language it is clear that the series deriving from personal pronouns $(-m,-t,-\check{s})$ is present in the object-oriented (here transitive) set of suffixes (with an added number morpheme in the plural), whereas the intransitive verbs display a different set of suffixes not deriving from PP-s. This distribution strongly resembles that seen in Hungarian.

4.2.2. Greenlandic (Paleo-Siberian, Esquimaux-Aleutian). ${ }^{11}$ Here we give the personal endings of the singular paradigm. Since we have no data on

\footnotetext{
${ }^{10}$ Based on Yaziki mira... (1999, 165-6).

${ }^{11}$ Based on Yaziki mira... (1997, 97-8).
}

Acta Linguistica Hungarica 51, 2004 
the personal pronouns, we compare the Vx-es of the transitive conjugation with the Px-es (possessive personal suffixes).

(3) Px-es: 1sg - ra, 2sg -t, 3sg -á.

Intransitive conjugation: $1 \mathrm{sg}-u \eta a, 2 \mathrm{sg}$-utit, $3 \mathrm{sg}-v o q$.

Transitive conjugation:

\begin{tabular}{llll}
\multicolumn{1}{r}{ Object: } & me & you & him \\
Subject: & & & \\
I & - & $-k i t$ & $-\gamma a$ \\
you & $-\gamma m a$ & - & $-t$ \\
he & $-a ́ m a$ & $-a ́ t i$ & $-a ́$
\end{tabular}

As can be seen, with 3sg objects - much like in Hungarian - synthetic Vx-es coincide with Px-es, for which the most probable explanation is that they derive from the same personal pronouns.

4.3. Further investigation of the languages with object-dependent verbal conjugation leads to the observation that the use of original personal pronouns in the object-oriented, rather than the unmarked, conjugations frequently occurs with analytic person-marking as well, though it is by no means unexceptional. Some examples follow.

4.3.1. Ersa objective endings: ${ }^{12}$

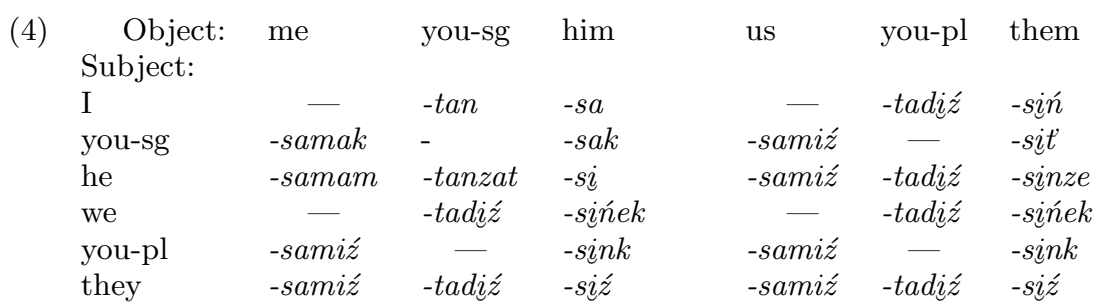

As will be seen at first glance, the similarities are especially transparent vertically (i.e., in relation to the object) rather than horizontally (i.e., in relation to the subject) in that in forms referring to a first person object ${ }^{*}-m$, in forms referring to second person objects ${ }^{*}-t$, and in relation to a third person object perhaps ${ }_{-}^{*}$ s(i) seems to appear consistently. This is exactly what one should expect if the marking of objects is related to the original Finno-Ugric personal pronouns. Similar etymologies cannot be given for subject markers.

${ }^{12}$ Based on Feoktistov (1966, 188ff). 
4.3.2. Koryak (Paleo-Siberian, Chukch-Kamchatkan language, ergative), leaving aside dual forms: ${ }^{13}$

Personal Pronouns: 1sg gimmo, 2 gičči, 3 inno, 1pl muju, 2 tuju, 3 ičču.

For transitive verbs the respective subject-marking prefixes are: $t i-$, $k(u)_{-}$, ne-, mit-, ko-/ku-, na(ku)-/ne(ku)-.

The object-marking suffixes are:

\begin{tabular}{lcclccc}
\multicolumn{1}{r}{ Object: } & me & you-sg & him & us & you-pl & them \\
Subject: & & & & & & \\
I & - & $-g i$ & $-i n$ & - & $-t i k$ & $-n e v ́$ \\
you-sg & $-\eta$ & - & $-i n$ & $-m i k$ & - & $-n e v ́$ \\
he & $-\eta$ & $-g i$ & $-n i n$ & $-m i k$ & $-t i k$ & $-n i n$ \\
we & - & $-g e$ & $-i n$ & - & $-t i k$ & $-n i n$ \\
you-pl & $-t i k$ & - & $-i t k i$ & $-m i k$ & - & $-i t k i$ \\
they & $-g i m$ & $-g i$ & $-i n$ & $-m i k$ & $-t i k$ & $-n e v ́$
\end{tabular}

As can be seen, neither the subject-marking prefixes, nor the objectmarking suffixes relating to the subject (horizontally) can be related to personal pronouns, but, at the same time, there is a clear connection (vertically) between the person of the object and the PP-s in second person in both numbers as well as in $3 \mathrm{sg}$ and $1 \mathrm{pl}$. (All the three series of morphemes - PP-s, subject-marking prefixes and object-marking suffixes - share a $1 \mathrm{pl}-m$, the pre- and suffixes also share a $3 \mathrm{pl}-n$, but this latter cannot be associated with the corresponding PP.)

4.3.3. Alaskan Yupik/Yuit (ergative, dual forms omitted): ${ }^{14}$

(6) (a) Intransitive endings: sg $\mathrm{pl}$

$\begin{array}{lll} & \text { sg } & \text { pl } \\ 1 & -\eta a & -k u t \\ 2 & -t \partial n & -c i \\ 3 & -\varnothing & -t\end{array}$

(b) Transitive endings:

\begin{tabular}{|c|c|c|c|c|c|c|}
\hline $\begin{array}{l}\text { Object: } \\
\text { Subject: }\end{array}$ & me & you-sg & him & us & you-pl & them \\
\hline T & - & $-m k ə n$ & $-k a(\varnothing)$ & - & $-m c i$ & $-n k a(\emptyset)$ \\
\hline you-sg & -рәұа & 一 & $-n(\varnothing)$ & -pəkut & - & $-\tan (\varnothing)$ \\
\hline he & $-\eta$ ya & -naton & $-\eta a(\varnothing)$ & -rakut & $-\eta a c i$ & $-\eta i(\varnothing)$ \\
\hline we & - & -mtyan & -put(Ø) & - & $-m t c i$ & -put(Ø) \\
\hline you-pl & -pәcina & - & $-c i(\varnothing)$ & -pәcikut & - & $-\operatorname{ci}(\varnothing)$ \\
\hline they & $-\eta a t \eta a$ & - yatyan & $-\eta a t(\varnothing)$ & -nitkut & $-\eta i t c i$ & - $\eta i t(\varnothing)$ \\
\hline
\end{tabular}

${ }^{13}$ Based on Yaziki mira... (1997, 49-50).

${ }^{14}$ Based on Miyaoka (1996, 328-9). 
As can be seen here, too, the intransitive ("subjective") endings occur in the objective endings of the transitive paradigm (represented vertically), which means that they refer to the object rather than the subject here. $^{15}$ (These endings correspond to items in the rather intricate personal pronoun system of Yupik in the first person as well as in 2pl; if the $\emptyset$ ending derives from an original non-zero element, then at two more points. Interestingly, the corresponding pronominal elements also occur as suffixes on unrelated stems.)

4.3.4. There are languages with analytic conjugations in which the Vx-es or portions of Vx-es deriving from personal pronouns refer to the subject but only on transitive verbs. North-West Iranian languages are of this type (Meimei, Jawshakani, Khunsari, Vonishuni, Käviri dialects, Sivandi). ${ }^{16}$

4.4. As will be apparent even from this limited set of examples, the Hungarian object-dependent conjugation - in which original Vx-es can be associated with the object-oriented (or objective) rather than the nonobject-oriented (or general) conjugation - is, in fact, not entirely specific to the Uralic family, let alone specific to this language. It follows from this that its evolution should not be explained with reference to specifically Uralic or specifically Hungarian developments. In line with this suggestion, we will develop in what follows an interpretation that is at once universalistic and applied to a particular language in proposing a new hypothesis. But in order to do this we must first survey what earlier explanations we mean to relate to.

5. Let us then take a look at the major types of explanations proposed in the literature for the historical development of the Hungarian subjective vs. objective (or indefinite/general vs. definite) contrast. The brief discussions below and the objections made are not put forward as an exhaustive listing of whatever has been said on this topic before us, and at each point we will only give a few references representative of the ideas under discussion instead of a full list. On certain occasions, particular

${ }^{15}$ With respect to ergative languages this appears fairly trivial since it simply involves the agreement of the verb with the noun in absolutive case/function. Nevertheless this means that the morphological makeup of verbs coincides exactly where, in a nominative terminology, we speak of the subject of intransitive verbs and the object of transitive verbs.

${ }^{16}$ Of other languages perhaps Naucan Esquimaux belongs here. 
theories will be referred to by some name other than is usual. This is done in order to facilitate their comparison.

\subsection{Agglutination hypothesis ${ }^{17}$}

According to this hypothesis, when the objective conjugation was formed, the morphological structure of the verb consistently reflected the three functions to be denoted: action + object + subject. This is exemplified to this day by forms like vár-já-tok 'you are waiting (for it etc.)'. The item - $j \bullet$ - derives from a personal pronominal element. Forms that now consist of two elements only used to be composed of three, e.g., várom 'I am waiting (for it)' going back to something like *vár $\bullet-j \bullet-m$.

This hypothesis of the origin of Hungarian objective conjugation is no longer held by anyone. It proved untenable on a phonological basis: the disappearance of the hypothetical object-marking morpheme of the form ${ }^{*} j$ • (and the corresponding syllable) is wholly unparalleled. It is also left unexplained that in the first and second persons singular it was the object-marking element that disappeared, whereas in the first and third persons plural it was the subject-marking element.

\subsection{Possessive Px hypothesis}

This has two versions, which may be termed semantic vs. syntactic.

5.2.1. According to the semantic version, ${ }^{18}$ the objective verb forms have always consisted of two parts and not of three, they never referred to the object. Objective Vx-es go back to Px-es, the original meaning of forms like várom 'I am waiting (for it)' is 'my waiting'. This is supposed to reflect an archaic way of thinking in which the action denoted by the verb is seen as the possession of the speaker. When the verb was accompanied by an object, the ending simultaneously or sequentially acquired the function of referring to the agent as well as the definiteness of the object.

The chief argument against this hypothesis is that deriving the Vx-es from possessive person-markers is semantically implausible. Even if the base of the future objective verb form was regarded as a nomen-verbum

${ }^{17}$ Hunfalvy (1862), Budenz (1890-1892).

${ }^{18}$ It is probably correct to say that this was the majority view up to the 1970 's. The originator of the idea may have been Thomsen (1912), the idea being picked up by Melich (1913). It was also propounded by the purported standard textbook of Finno-Ugric studies (Osnovi 1974, 321) and persisted until the very end of the century (Lommel 1998). 
(which only could have made it possible for it to take Px-es), it is not at all clear why in a verb + object structure the action rather than the object would be understood as a possession. This possessive interpretation is supported by nothing else than the idea that the morphemes in question are supposed to have been Px-es, thus the argumentation is circular. Furthermore the nomen-verbum hypothesis in itself must be rejected if we note that in Pre-Hungarian, probably the period of the emergence of the objective conjugation, nouns and verbs were already very clearly distinguished and even the very few ambiguous stems that existed could not be found in both functions at the same time; thus their categories did not lend themselves to analogical transfer. ${ }^{19}$

5.2.2. According to the syntactic version ${ }^{20}$ Px-es were reinterpreted as Vx-es in sentences with a participial predicate. The reanalysis then took the following form:

$\begin{array}{llll} & \begin{array}{l}\text { hal/halam } \\ \text { (my) fish }\end{array} & \begin{array}{l}\text { (a) nö } \\ \text { (the) woman }\end{array} & \begin{array}{l}\text { fözte } \\ \text { cooked }\end{array} \\ \text { 1. original } & \text { subject } & \text { possessor } & \text { nominal predicate (participle) } \\ \text { 2. innovative } & \text { object } & \text { subject } & \text { verbal predicate }\end{array}$

This explanation crucially depends on the hypothesis that the object as well as the possessor were originally unmarked.

The objection against the previous explanation, viz. that in PreHungarian, the period when the language was already separated from its relatives, nouns and verbs were no longer undifferentiated, cannot be made here. This argument is based on participles, whose dual nature is evident (hence their traditional name), and their appearance within the verbal conjugation is well known for both Indo-European and FinnoUgric. We can also make no objection against the hypothesis that the object as well as the possessor were unmarked. The problem lies elsewhere. In its supposedly original meaning this sentence type ('The fish is the woman's cooking') seems rather eccentric even for Pre-Hungarian and, since it predicates an acquired trait of the subject, it is, as a consequence, highly restricted. Transitive verbs that do not assign a new characteristic to the subject could hardly, if at all, be involved ('the fish is the woman's seeing, eating, wanting, waiting' etc. as answers to the question 'what is the fish like?'). It is also not clear why this participial sentence type

19 This objection is made by Rédei $(1989,180)$.

${ }^{20}$ Klemm (1928-1942, 119-20). 
could not consist of a predicate and an indefinite, rather than a definite, subject ('a fish is the woman's cooking'), but such constructions did not give rise to an objective conjugation. In this explanation it is also tacitly assumed that the objective conjugation developed in the past tense, since the present forms fözöm, fözöd, fözi 'I/you/he cook(s)' cannot originate from (predicative) participles, which would be a prerequisite for attaching a Px. What this implies is that present objective forms all developed on the analogy of the past objective forms - which is by no means implausible, but certainly needs further confirmation. It is also to be noted that in the third person such deverbal nouns with Px often differ from the corresponding verb form in Modern Hungarian: föztje 'his/her cooking' vs. fözte 'he/she cooked'. This explanation would thus imply that - at least in 3sg forms - the current shape of the Px is a later development relative to the shape from which the (objective) Vx is supposed to have been originated. In sum, while all this does not falsify the hypothesis, it also definitely does not make it look plausible.

\subsection{Non-possessive Px-hypothesis ${ }^{21}$}

In this hypothesis, objective Vx-es are related to Px-es, though not in a possessive sense, but - similarly to their original function - as markers of definiteness, in particular the definiteness of the subject. It is this determinative role that explains why original PP elements appeared in the objective conjugation. The function of determining the subject was then reinterpreted as a function of determining the object. In 1sg there was, in the beginning, only $-m$, but "there was a clear tendency in the language to distinguish the subjective and the objective conjugations (also in 1sg) with different person-markers; and to achieve this, of the 1pl person-markers -uk/-ük (turning later into -ok/-ök through the lowering of the vowels) was reinterpreted as a 1sg person-marker". ${ }^{22}$ An analogous process took place in Finnish as well: the plural marker - $t$ in meidät 'us' appears in 1sg: minut 'me'.

The following objections can be made against this hypothesis. The shift from the function of determining the subject to the function of determining the object is highly dubious even in the third person - all we know for sure is that the $\mathrm{Vx}$ in question now marks the definiteness of the object. If it ever marked the definiteness of the subject, we would

\footnotetext{
${ }^{21}$ Rédei (1962).

${ }^{22}$ Rédei (1962, 427).
} 
expect it to turn up in the subjective conjugation too, since the subject can also be definite. In $1 \mathrm{sg}$ and $2 \mathrm{sg}$, however, this idea makes no sense whatever, given that the subject (I, you) need not and indeed cannot be made more definite than it is. The reinterpretation of $-k$ from plural marker to a singular $\mathrm{Vx}$ is also implausible because in $2 \mathrm{pl}$ and $3 \mathrm{pl}$ the same segment can only be analysed as a plural marker in comparison with the corresponding singular forms and thus it is hard to understand how this could have been "overlooked" in 1pl, a form morphologically parallel to the other two. (The meidät $\rightarrow$ minut change is not really a good analogy in that in meidät the - $t$ is already a marker of the accusative as well and it was in that capacity that it was carried over to minut, whereas the $-k$ in $-u k /-\ddot{u} k$ does not refer to first person.)

\subsection{Depassivisation hypothesis ${ }^{23}$}

This hypothesis presupposes that the 3sg forms *vár-já/kér-i 'he waits/ asks' could also be used in a passive sense, and in that case the $-j a ́ /-i$ (going back ultimately to Proto-Finno-Ugric * se) refers to a passive 3sg subject ('he is waited for/he is asked'). This was accompanied by the exponent of the active subject, as can be seen e.g., in 2pl: várjá-tok/ kéri-tek 'you wait for him/ask him'). The same stands for forms like 1sg váro-m: vár $\bullet$ - was originally a composite form: vár $\bullet+\varnothing$, where $\varnothing$ is the exponent of the passive subject (= active object) 'he is waited for', to which then $-m$ is added as the marker of the $1 \mathrm{sg}$ subject, thus 'he is waited for by me' = 'I wait for him' (mutatis mutandis in $2 \mathrm{sg}$ ).

This hypothesis is either self-contradictory or is based on unproved premises. Let us begin with the forms * vár-já/kér-i 'he waits/asks', which supposedly include the agglutinated third person pronoun. If this latter really referred to the subject (next to a semantically passive stem), it could not have been suffixed further as in vár-já-tok 'you wait for him' because in this form two different subjects would have been marked. If, however, the element $-j a a^{-}$happens to refer to the object (which would explain the emergence of the form vár-já-tok), then the stem could not have been understood as passive, and consequently the assumption that it was passive in the first and second persons is either totally unfounded - and unparalleled in the third person - or the stem was not passive even in the first and second persons, whereby the entire explanation is undermined. The only possibility left is that $-j a a^{-}$was originally added to

\footnotetext{
${ }^{23}$ Papp $(1942 ; 1968)$, generally known as condensation or resuffixation theory.
} 
a passive stem, but the whole form was later - but before the emergence of the plural forms - reinterpreted as active. There is no more evidence for this than for the assumption that the stem was interpreted as passive in the first and second persons. Nevertheless the explanation clearly has a certain elegance to it: the stem was originally passive in all the three persons in the singular, the Vx-es deriving from original PP-s mark the subject, then the forms are reinterpreted as active and the Vx-es are reanalysed as markers of (third person) definite objects, and the third person marker thus appears as such in the plural forms. The indefinite conjugation may have been formed in contrast to the definite paradigm when the verb stems had already been reinterpreted as active (otherwise the meaning of várok would not have differed from that of várom). However, there is a price to pay for the elegance of the argument. This is the two unproved assumptions on which it is founded, viz. that transitive verbs were originally interpreted as passive and that the Vx-es were reanalysed as markers of a third person object. Furthermore, not even a passively interpreted verb stem guarantees that its subject (later object) should be understood as definite, thus the derivation would be impeccable only if transitive verbs in Hungarian could only be conjugated according to the objective paradigm (or, as a third assumption, the definiteness of the object must be included). ${ }^{24}$ In addition, if such a reanalysis of the $1 \mathrm{sg}$ and $2 \mathrm{sg}$ suffixes could be proved, assuming the depassivisation of the stem would be rendered superfluous, ${ }^{25}$ since the question is not whether the latter was ever regarded as passive, but why $-m$ and $-d(<* t)$ refer to the object (too) and why they happen to be part of the definite paradigm. In sum, the depassivisation theory is elegant at the cost of in fact assuming everything it sets out to explain.

\footnotetext{
${ }^{24}$ And there is a fourth, hidden, point here: what are we to say about intransitive verbs? If in the case of transitive verbs the pronouns referred to the subject, we could expect them to appear on intransitive verbs as well (since the subject is third person there as well), or, alternatively, we have to claim from the beginning that in Pre-Hungarian intransitive verbs were semantically always active, whereas transitive verbs were always passive, which would then explain the zero-morpheme intransitive forms. Such an account would not be absurd at all - for instance, in a language with an active syntactic pattern or in the reconstructed prehistory of an ergative language such a state of affairs would be highly in harmony with the structure in general - but the nominative nature of Hungarian as well as the comparative Finno-Ugric evidence preclude this assumption for Pre-Hungarian.

${ }^{25}$ The Vx in váro- $m$ refers to the subject and is to be reanalysed as claimed above even if the stem of the verb form was always active.
} 


\subsection{The object pronoun hypothesis}

This exists in two forms: in one, the pronoun in its pure form, in the other the pronoun in the accusative case, was putatively agglutinated to the relative verb stem.

5.5.1. The first version ${ }^{26}$ is based on the assumption that the agglutinated third person pronoun was a marker of the definite object already in the proto-language. If accompanied by an indefinite object, or no object at all, the verb form used was the pure stem without person-markers or a form including a participial suffix. The chief and perhaps original role of the objective forms was anaphoric (i.e., it was used in the absence and instead of an actual object). The participial form then - precisely because it marked no person - infiltrated into the first and second persons (in the indefinite conjugation). To distinguish between subjective and objective forms participles were used and all of the subjective endings may have been participial suffixes.

The problem with this explanation is again that it only applies to the $3 \mathrm{sg}$, not to the other two persons. The ${ }^{*}-m e$ and ${ }^{*}$-te of the first two persons could not have been anaphoric at all: they could not originally refer to the object since in the syntactic environment of the verb form not the object but the subject was first or second person. An analogical explanation - viz. that it was only the addition of the PP that was copied from the $3 \mathrm{sg}$ - will not do either. Besides running into the same semantic problem, it also presumes that in the present tense $-m$ and $-d(<* t)$ did not actually occur in $1 \mathrm{sg}$ and $2 \mathrm{sg}$, respectively, before the emergence of the definite $3 \mathrm{sg}$ form, which is virtually impossible; suffice it to refer to the past tense, where $-m$ is also found in the indefinite conjugation.

5.5.2. In the other version, ${ }^{27}$ too, it is held that the pronoun originally had an objective-anaphoric function, but it is assumed that in the definite conjugation it is the accusative form of the personal pronoun that served as the ancestor of $\mathrm{Vx}$, and it is emphasised that a personal pronoun object could not possibly be in the nominative case. The longer pronominal forms are more likely indeed because the endings in the objective conjugation are more like Px-es than like indefinite Vx-es, of which the former clearly appear in the Finnic languages to have been longer originally than Vx-es (cf. kanna-n but talo-ni etc.), the personal pronouns

\footnotetext{
${ }^{26}$ Rédei (1989).

${ }^{27}$ Honti $(1996 ; 1998 / 1999)$
} 
in these cases also seem to have taken a genitive ending. The place of the personal pronoun in the accusative was - in harmony with the SOV pattern - immediately before the Vx (though, in fact, in 3sg, where the objective conjugation was actually born, this Vx was zero, consequently the pronoun marked as object could soon assume the function of marking the $3 \mathrm{sg}$ subject). This system probably only existed in the third person for a long time, but with time it was analogically extended into the first and second persons, i.e., the element deriving from PP-3sg-acc appeared in these forms as well before the subject-marking Vx-es - in contrast to the corresponding indefinite forms. The same may have happened later to forms expressing first and second person objects. All this is not a hypothesis about the precursor of current objective conjugations but about the proto-language.

This hypothesis is very much like the agglutination hypothesis mentioned as the first in this discussion above in its general principles (though not in its particulars), in that while deriving its putative history it arrives at the same ideal and transparent pattern: the indefinite and the definite forms of the same person and number differ consistently in the presence vs. absence of the element marking the object (here $\mathrm{PP}+$ acc). While we do not dispute the potential relevance of this hypothesis with respect to Proto-Uralic and Proto-Finno-Ugric (although the VOS morpheme sequence of the emerging verb forms is hardly coherent with the SOV sentence pattern - given that it matters greatly what the object precedes in the penultimate position, and but a very small number of languages of the sentence pattern VOS is known to exist anyhow - , and a further surprising consequence of the hypothesis is that the objective conjugation is not predicted to have emerged where it is now actually found but to have withered away where it is not...), we can certainly claim that in explaining the actual formation of the objective conjugation in Hungarian specifically in the first and second persons - it is of no use whatsoever. Just like the agglutination hypothesis, it fails to explain how the objectmarking element could have disappeared from the $1 \mathrm{sg}$ and $2 \mathrm{sg}$ forms of the definite conjugation (especially without phonological consequences) if this, and only this, was the difference between the corresponding definite and indefinite forms in the respective conjugations. Furthermore, no hint is provided about the origin of the endings found in the subjective paradigm (one may assume, of course, that after the - unexplained disappearance of the objective element a new solution had to be found 
for differentiating the two conjugations; we will return to the problems such an explanation would pose in the next point).

\subsection{Parallel accusative hypothesis ${ }^{28}$}

This hypothesis crucially involves the claim that the emergence of the objective conjugation is a development wholly internal to Hungarian. At the beginning of the Pre-Hungarian period the object was unmarked, but after a while the definiteness (the anaphoric, thematic role) of the object had to be marked with a dedicated morpheme. The appearance of the accusative $-t$ suffix and of the definite conjugation happened in tandem. When the suffix - $t$ was extended from definite objects to objects in general, the marking of definiteness was left to the verbal endings. But this necessitated the introduction of person-markers that did not refer to a definite object. This is how the general conjugation was formed. Furthermore: "It is clear that in the process of the crystallisation of the definite conjugation, in $3 \mathrm{sg}$ as well as in $2 \mathrm{sg}$ it was a suffix deriving from the personal pronoun that appeared in the paradigm..." ${ }^{29}$ It inevitably follows from this idea that the conjugation of intransitive verbs developed only after, and analogically modelled on, the conjugation of transitive verbs with an indefinite object.

The logic behind this argumentation implies that the first stage there involved unmarked objects and a single type of conjugation. The following steps can then be evaluated depending on whether the claim that the appearance of the accusative - $t$ suffix and of the definite conjugation happened in parallel is understood as referring to the entire process or only its inception.

(a) If the claim is interpreted more generally, then in the second stage, which followed a period of a monolithic conjugation and unmarked objects, unmarked indefinite objects stand in contrast to marked definite objects, but the verbal conjugation is still homogeneous, in other words, the definiteness of the object is only marked on the object itself. The third stage can then be envisaged in two different ways. (a/i) In some way there appears a difference between the general and the definite conjugations and the latter indeed assumes the function of marking definiteness. As a consequence, the suffix of the definite object is rendered redundant in that determinative function and is extended to all objects

\footnotetext{
${ }^{28}$ Abaffy (1991, 128).

${ }^{29}$ Abaffy $(1991,130)$.
} 
in the capacity of marking 'object in general'. In this case the emergence of the definite conjugation is - contrary to the hypothesis - independent of the marking of the object. (a/ii) The accusative suffix is extended to all objects while the conjugation remains homogeneous. This means, on the one hand, that the language lost the capacity to mark the definiteness of the object and, on the other hand, that no definite conjugation comes into being. It is impossible to assume a stage at which the conjugation is already definite, while nominals no longer, and verbs do not yet, mark definiteness. Definite and indefinite conjugations can only exist simultaneously, in relation to each other. To say that a certain category is not expressed in a certain language (at a given stage) is equivalent to the claim that that category does not exist in that language (then and there). Any claim to the effect that it is there in principle or that the language requires it despite its absence, is uniterpretable.

(b) If the parallelism between the emergence of the $-t$ accusative suffix and the objective paradigm is understood as holding only at the inception of the process, i.e., the marking of the definiteness of the object appeared simultaneously on the object and the verb, then it is implied that the definite object came to be accompanied by verb forms of a definite conjugation, since the earlier verb forms obviously went together with the indefinite objects. But if this was the case then the two conjugations were differentiated already before the extension of the $-t$ suffix to all objects and the fact that marking definiteness was "left" to the verbal suffix only need not have led to the appearance of an indefinite conjugation, since it had existed earlier.

The conclusion that we can draw from both (a) and (b) above is that no matter how the two conjugations came to be differentiated in Hungarian, this process cannot have been related in any way to the emergence of the $-t$ suffix and the changes in the range of its use. ${ }^{30}$

\footnotetext{
${ }^{30}$ Note that while Abaffy explains the appearance of the objective conjugation with reference to the suffix - $t$, she also implies the opposite in deriving the 3 sg suffix $-i k$ from the $3 \mathrm{pl}$ suffix $-i k$, viz. that the objective conjugation existed already when the object was still unmarked: otherwise it would be totally impossible to start out from a reanalysis of a fa törik 'they are breaking the wood' $\rightarrow$ 'the wood is being broken'. (Given the correspondences tör : tör-i : tör-i-k one cannot think that when the form törik already existed it was not an objective form - in contrast to the correspondence tör : tör-nek-since the $-i<{ }^{*} s i$ in it is nothing else but the object-marking element. The word $f a$, however, had to be unmarked as object otherwise it could not have been interpreted as subject.) Cf. Abaffy (1991, 125-7).
} 
As for the intrusion of the original personal pronouns into the $2 \mathrm{sg}$ objective verb forms in the process of the crystallisation of the definite paradigm, this hypothesis implies either that it only happened along with the appearance of definite objects (what was there earlier on the verb? was it the indefinite ending? does this mean that the $-l$, -sz endings are older than $-d<{ }^{*}-t$ ? and is then the indefinite paradigm older than the definite?), or that the pronouns had always been attached to the verbs but originally they did not function as endings marking definite objects, which then defuses the argument based on the analogy of the $3 \mathrm{sg}$ forms, because, in the case of the latter, it is known for certain that the element $-j a ́ /-i$ is an addition, i.e., an innovation vis-à-vis the earlier, unsuffixed (or zero-suffixed) form, and that it marked the definiteness of the object from the beginning.

\subsection{No suffix hypothesis}

The last hypothesis of the emergence of object-dependent conjugation we mention here is based on the assumption that in the beginning there was an unsuffixed subjective and a suffixed objective series of verb forms, of which the latter may have involved postponed PP-s. ${ }^{31}$ This means that in Pre-Hungarian the subjective paradigm included forms like én vár, te vár, ö vár 'I/you/he wait(s)' (with a final vowel identical and non-functional in all cases), since only this could later give rise to the $-k,-s z,-\varnothing$ series. Of this the $1 \mathrm{sg}$ was the first to go, as the story of vagy 'you are' and megy 'he goes' suggests (viz. that these two could both be $2 \mathrm{sg}$ and $3 \mathrm{sg}),{ }^{32}$ and the current forms of $2 \mathrm{sg}$ are later developments.

${ }^{31}$ Gombocz (1930); Nyíri (1974); Wacha (1974); Juhász (1999) etc.

${ }^{32}$ What this means in particular is that megy and mégy used to be one and the same and that vagy could also be a third person form as the pristine mascot names Mavagy, Nemvagy attest. (In this context the etymologies of the conjunctions vagy, avagy 'or' can also be mentioned, but these presuppose that the analysis of the verb forms suggested above is right, and cannot be taken as the only possible explanation anyhow.) We think that this argumentation is not difficult to find fault with. Megy and mégy probably never occurred in one and the same variety of the language, the $2 \mathrm{sg}$ vs. $3 \mathrm{sg}$ contrast goes back, in all likelihood, to an earlier mégy $\leftrightarrow$ mén or megyen contrast, and megy (ending in an affricate, which cannot have developed word-finally) either shortened from megyen or assimilated analogically to the forms of the other persons. The final consonant of mégy and the (compensatory) lengthening of its vowel (just like that of other apparently suffixless stem-2sg forms like lész 'you will be') is in want of an explanation anyway, and it is most likely that there was an earlier suffix after the stem. The 
This hypothesis appears to us unfounded. First let us note that the most important question, viz. why verbs complemented with a definite object should be conjugated differently from other verbs is not even posed, but it is simply presupposed that this has always been the case. (Thus the explanation for the emergence of the objective conjugation is that it has always been there.) The claim regarding the stem of the indefinite Vx series is similarly erroneous: this series of suffixes may have emerged not only through agglutination to a pure stem but also through the replacement of earlier agglutinated endings. But, above all, such a scenario is utterly unlikely from the point of view of typology and comparative Finno-Ugric studies. The latter unequivocally indicate that the Vx-es of $1 \mathrm{sg}\left({ }^{*} M\right)$ and of $2 \mathrm{sg}\left({ }^{*} T\right)$ go back to ancient personal pronouns which are found attached to the end of the verb stem from Proto-Uralic through Proto-Ugric. ${ }^{33}$ Thus even if the postulated "suffixless paradigm" had ever existed in Hungarian (unlike in its closest relatives!), it could only have arisen through the disappearance of the original Vx-es in the separated stage of the history of the language. This would mean an agglutinating $\rightarrow$ isolating change for the verb forms followed by a later stem-final agglutination again to arrive at the present-day forms. This would run completely contrary to the known tendencies of historical typology; fur-

3sg function of vagy is not proved by mascot names (as charms they may have been $2 \mathrm{sg}$ ), and the original 3sg form must have been vagyon. (The usual explanation of van 'he is' as coming from vannak 'they are' is also problematic: an assimilation * vagynak > vannak is no more plausible - cf. the form vagytok 'you.pl are' where the sound marked by gy did not fully assimilate to a consonant much closer to it in articulatory terms - than a shortening vagyon $>$ van, in which case vannak is the plural of this latter form.)

${ }^{33}$ Cf., among others, Hajdú (1966, 141-4). Csúcs (2001) claims this only of transitive verbs in Proto-Uralic, viz. that the highlighted object was before the verb and this is why the PP indicating the subject (also in $3 \mathrm{sg}$ ) was moved to a post-verbal position. First of all, the preposing of the object does not automatically entail the postposing of the subject, which would anyhow contravene the almost universal regularity of the subject coming before the object in the basic constituent order. The hypothesis is further weakened by the fact that even in those Uralic languages where there is no objective conjugation, the PP agglutinated to the end, and not to the front, of the verb; the same happened to intransitive verbs in languages with non-person marking object-dependent conjugation; and the same can be said of Indo-European languages. (In fact it has not been convincingly clarified for any of the SOV- or SVO-type nominative languages why the subjectmarking Vx-es that go back to PP-s are found at the end, rather than at the front, of verbs. The expected paths of change are shown most clearly by French, but that is a relatively recent development; more on this later.) 
thermore, a series like én vár, te vár etc., even if agglutinated, should have given rise to a prefixing series (as it happened to French je, tu etc., though not indicated in the spelling). On top of all that, the existence of a contrast like én vár $\leftrightarrow$ várom would have made the emergence of the present-day general conjugation superfluous anyhow. And what shall we say about the 1 sg suffix $-m$, which turns up in the subjective-general past and in the present forms of the "ik-verbs", mostly intransitive to this day, which is then claimed to have extended to its present positions from a function of marking exclusively definite objects?

6. Thus we have not found a fully satisfactory explanation. While some parts of the hypotheses here surveyed are perhaps dated, the majority of them may nevertheless include points worth considering, even if the hypotheses in their entirety contradict and thus mutually exclude each other. But now let us concentrate on those problems that occur in this whole list of explanations or at least in their majority.

6.1. The explanations that seek to explicate the emergence of the objective conjugation in the third person cannot explain the evolution of the first two persons along the same lines, because in 3sg the marker of the object, whereas in the other two persons the marker of the subject appears in the paradigm. ${ }^{34}$ Reference to the analogy of an autonomously developing third person form is not convincing either: if in the first two persons the verb forms are supposed to have consisted of three parts originally, the disappearance of the object-marking element, which was the only distinguishing factor between the definite and the indefinite forms in the same person, is inexplicable. If, however, the objective forms in the first two persons consisted originally of two parts, then the Vx3sg, which agreed with the person of the object, cannot have been the pattern on which the Vx1sg and the Vx2sg, marking the subject, were modelled.

6.2. Those hypotheses that explain the development of the objective conjugation in Hungarian with a new development of the reference to definite objects have to countenance the contradiction that this novelty emerged in a form based on the ancient PP-s in the case of the $1 \mathrm{sg}$ and $2 \mathrm{sg}$, while in the semantically "unmarked" indefinite conjugation, which should have

${ }^{34}$ The depassivisation hypothesis is an exception to this because there it is suggested that the pronominal element in the $\mathrm{Sg} 3$ is a subject, but this can only be done, as we pointed out, at the price of regarding the whole verb form passive - an unwarranted conclusion to our mind. 
developed earlier than the definite conjugation, more recent elements are seen (at least more recent as Vx-es).

6.3. Reference to an original function of marking an object that is not present in the sentence as the cause behind the development of $3 \mathrm{sg}$ forms again gives no answer but begs the question instead why only definite objects could be marked in such a way by a pronoun? Indefinite objects, when not present in a nominal form, should also have been replaced by pronouns.

6.4. Any hypothesis that claims that the indefinite conjugation emerged later than the definite one and thus implies that the current indefinite conjugation appeared as a "counterpoint" to the definite conjugation in order to mark the non-definiteness of the object, must necessarily lead to the conclusion that the current general conjugation came into being through the extension to intransitive verbs of the indefinite conjugation, originally confined to transitive verbs. But this is far not so obvious as it seems. Let us look at the supposed development of the 1sg forms:

$\begin{array}{llll} & \text { intransitive verb } & \begin{array}{l}\text { transitive verb }+ \\ \text { indefinite object } \\ \text { adom }\end{array} & \begin{array}{l}\text { transitive verb } \\ \text { definite object }\end{array} \\ \text { initial stage } & \text { futom } & \text { adom } & \text { adom } \\ \text { intermediate stage } & \text { futom } & \text { adok } & \text { adom } \\ \text { final stage } & \text { futok } & & \end{array}$

Analogical innovation cannot be conceived of as spreading like an infectious disease. Analogy always means generalisation. To see an analogy between two phenomena - within language as well as elsewhere - consists in seeing their common traits as essential and their differences as unimportant, irrelevant for one's actual concerns. Deriving the final stage from the intermediate stage in this case would mean that the language gives precedence to the analogy between being accompanied by an indefinite object and lacking an object altogether over the syntactic difference between intransivity (monovalence) and transitivity (bivalence). Since this analogy clearly cannot be syntactic in nature, it has to be semantically based. But the claim that the semantic aspect of the analogy is the "action not being oriented towards a definite object" is highly spurious (and simply posits the outcome as its own explanation) - yet we know of no other suggestion. If the general conjugation developed in Hungarian as the generalisation of the conjugation of the verbs accompanied by an 
indefinite object, this is to be treated not as trivial evidence but as a serious challenge to anyone involved in Hungarian diachronic linguistics. ${ }^{35}$

7. It is time now to come forward with our own suggestions.

7.1. First of all a distinction has to be made between the appearance of object-oriented (in Hungarian definite) conjugation in the third person and in the first and second persons, since the outcome is different too. In third person singular (and later in the plural) it is clear that the hypothesised pronoun ${ }^{*} s e\left({ }^{*} s e-m\right.$ ? $)$ referred to a third person object and not to a subject, ${ }^{36}$ which - as we pointed out several times - is different in principle from the other two persons, where the Vx-es obviously only marked the subject originally. Furthermore, an anaphoric function of this pronoun is only conceivable in the third person, since in the case of first and second person subjects (speaker and addressee) there was neither need nor possibility to refer back to anything. ${ }^{37}$

Thus it can be safely assumed that the objective $3 \mathrm{sg}$ forms go back etymologically to the combination of a verb stem and a $3 \mathrm{sg}$ pronoun, and the otherwise important question whether this was a personal or a demonstrative pronoun ${ }^{38}$ and whether it was represented in its base form

${ }^{35}$ It also does not help if we assume that the general conjugation appeared simply in contrast to the transitive conjugation all at once. This is a shortcut to the same problem: while the emergence of the objective conjugation point to the salience of the principle of transitivity, blurring the line between intransitive verbs and transitive verbs with indefinite objects points to the opposite.

${ }^{36}$ As we said earlier, Csúcs (2001) argued for the opposite, but is not convincing (see note 33).

${ }^{37}$ Given the uncontested etymologies of the Uralic pronouns - as well as of the large part of Px-es and Vx-es - it would be futile to assume a stage at which a Sg1 subject would speak of himself or of the addressee in the third person. The use of full nominal elements as subjects was thus only possible when a real third person was involved, and so it was only in these cases that pronouns had anything to replace. But, as we have seen, even then this did not happen, since the pronoun refers to the object and not the subject.

${ }^{38}$ In Hungarian and in the Finno-Ugric languages generally it was clearly a personal pronoun, but in other languages it may well have been a demonstrative pronoun. Actually, in 3sg the two categories may just as well have been indistinguishable (in as much as the same pronouns were used for objects and persons, as it still is the case, at least in part, in Hungarian, especially in 3pl: Megkaptad a könyveket? Meg, de még nem olvastam őket. 'Have you got the books? Yes, but I haven't read them yet'; the form azokat 'those' instead of oket, currently promulgated by purists, is not archaic). 
or in the accusative ${ }^{39}$ after the verb is irrelevant from this point of view. The essential point is that in these forms the pronoun appears behind the verb in order to mark the object. ${ }^{40}$ The question is to what period we can date this development. As is well known, the 3sg distinction between an unsuffixed non-object-oriented and a person-marked object-oriented form can be plainly demonstrated for Hungarian, Vogul, Ostyak, Mordvin, Nenets, Enets and Nganasan. ${ }^{41}$ This could theoretically point to these particular forms going back to Proto-Uralic. On the other hand, the same distinction is unknown in the rest of the Uralic languages, which either renders the dating to Proto-Uralic impossible, or leads to the assumption that these languages also possessed the original Proto-Uralic contrast but got rid of it with the passage of time. There is, however, no evidence whatever to support the latter hypothesis.

We think the contradiction can be circumvented only if we give up the assumption that this pronoun was already agglutinated in the protolanguage and instead of an objective verb form we hypothesise an objectively constructed verbal phrase. What this means is that when the nominal element functioning as the object was not present in the immediate environment of the verb, a pronoun referring to a third person object appeared there. This "absence" of the object is usually interpreted in such a way that the pronoun fulfils an anaphoric role: it replaces an already mentioned nominal object. While this is possible, we think that, of the three possible spheres of use (deictic, anaphoric, cataphoric), anaphoric is the youngest. Given that communication did not happen in carefully constructed and worded discourse and especially not in texts detached from the relevant situation (and thus fixed, and interpreted only later), but the exchange of information took place in a living speech community in the concrete actuality of a variety of situations, deixis (i.e., reference outside the discourse, to the speech situation) may very well have been more frequent than anaphors. Yet we would put cata-

${ }^{39}$ At this point let us only note that even if this accusative ending could be demonstrated for the Uralic languages, other languages showing object-dependent conjugation prove that this is not a prerequisite of the emergence of the 3sg objective form.

${ }^{40}$ Previously it was also thought that in 3 sg there were two possible endings $(\emptyset$ and $-?<$ PP), with objective reference being added only later (Mészöly 1931, 65ff; Berrár 1957, 54). This clearly contradicts what we know of the Finno-Ugric languages that have objective conjugation, and it also leaves the phenomenon unexplained.

${ }^{41}$ Hajdú (1966, 75, 1985, 245); Rédei (1989, 185), etc. 
phor (forward reference) first. This is because pronouns constitutedespite their traditional name - a more ancient and by nature more general (not more generalised but more undifferentiated) syntactic category than nouns. Even today they are not only used to refer to what is already known but also to syntactically represent items that are only hypothetical in terms of some possibility or generality, and not more specific than that. What we find most likely is that speakers indicated the object associated with a transitive verb with a pronoun, and then explicated it with a postposed, additional nominal element (noun). ${ }^{42}$ This structure must have alternated with the immediate presence of the object, i.e., *kanta se $(m)$, kala $(m)$ and *kanta kala $(m)$ could both be used to mean 'he brings the fish'. In those languages where the latter - in a certain sense progressive - entirely replaced the pronominal structure, object-dependent conjugation never developed and thus never existed. ${ }^{43}$ In those languages where the former syntagmatic structure - in our view more primitive in a sense - stabilised, after a syntactic reanalysis and a stress shift there emerged the possibility for the pronoun to agglutinate, whereby a verb form with object-oriented suffixation came into being. The objective conjugation thus developed in some of the daughter languages from the same ancestral syntactic structure, materially the same $3 \mathrm{sg}$ pronoun and via a process that is in broad outlines the same and yet we need not assume that the eventual agglutination took place in the proto-language. In other words, the third person objective verb form in the Uralic family has its motivation, though not its etymological origin, in Proto-Uralic. We suggest that the same can be said with respect to object-dependent conjugation as an organising principle. This hypothesis, viz. that what we see here is the independent actualisation in the daughter languages of a potentiality that goes back in etymological as well as syntactic terms to the proto-language, helps to circumvent the - mostly implicit-problem, too, of how the objective conjugations of the affected languages can be so different if they go back to Proto-Uralic.

${ }^{42}$ Such structures have been gaining currency in Romance languages recently: je la vois, la tour Eiffel!, etc. In Hungarian the congruence of demonstrative pronouns is a development parallel to this: *látom azt, a házat 'I see that, the house' $\rightarrow$ látom azt a házat 'I see that house'; *abból, a kosárból vette ki 'he took it from that, the basket' $\rightarrow$ abból a kosárból vette ki 'he took it from that basket', etc.

${ }^{43}$ For some of the Finno-Ugric languages (Permic, perhaps Cheremis) it is assumed that a development along these lines began but terminated at some point. These cases, however, represent internal developments and not the disappearance of something inherited from the proto-language. 
Going back to Hungarian then, it seems clear that the emergence of the 3sg objective verb form followed a simple path: a PP3sg was agglutinated to an originally unsuffixed verb stem. ${ }^{44}$ But it is also clear that this should have resulted in a semantically extensive transitive conjugation (i.e., it does not yet explain why this verb form only refers to definite object), in other words what has been said above does not fully account for the present state of affairs even in 3sg. Nevertheless, if this is a hypothesis along the right lines, there must have been a period in the history of Hungarian after its separation from the rest of the family when the objective conjugation already existed in the third person but not yet in the other two. The relevance of this should not be overestimated even though it follows clearly that sentences were organised on different principles in the case of the third person than in the first and second persons. The objective-subjective distinction in the third person - which, being extensive, was not identical to its modern reflex, also attested in the other two persons - could serve only as a background, as a functional, but not structural, starting point for the latter. ${ }^{45}$ This is because the scheme of syntagmatisation is inapplicable to the first and second persons (such a process should have led to entirely different results). The 1sg and 2sg objective forms must be explained along different lines.

7.2. Let us now turn to the problem of the first and second persons.

7.2.1. As we have seen, all the hypotheses that - while accepting the ancestral status of the $-m$, - $d$ suffixes - hold that the emergence of the objective interpretation of these endings in $1 \mathrm{sg}$ and $2 \mathrm{sg}$, respectively, diachronically and/or logically preceded the other endings (now called indefinite or general), take it for granted that the non-object-oriented conjugation is the negation of the object-oriented conjugation in its origin

\footnotetext{
${ }^{44}$ As far as we can judge there is no evidence of an ancestral accusative suffix on the pronoun in Hungarian; if it had ever been there it must have been apocopated before the emergence of the $3 \mathrm{pl}$ suffix $(=3 \mathrm{sg}+-k$, the latter being the plural suffix), let alone the other two plural forms.

${ }^{45}$ And was by no means dominant, given that it only encompassed one third of the verb forms. In present-day Hungarian not only third person but also secondperson objects may trigger objective conjugation $(-l a k /-l e k)$, i.e., the objectdependent system now encompasses more than half of the possible subject-object combinations $(1-3,2-3,3-3,1-2)$, but there are no signs of its extension to the rest of the combination (2-1, 3-1, 3-2, which still trigger the general conjugation). This makes it futile to meditate on the extension of third person object-dependent conjugation as a basic motivation for change.
} 
and essence. The logic of the diachronic process in these hypotheses can be represented on the $1 \mathrm{sg}$ as follows:

(9)

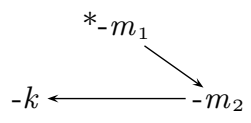

That is, the original, only and thus undifferentiated $\mathrm{Vx}\left({ }^{*}-m_{1}\right)$ first assumed the function of referring to definite object $\left(-m_{2}\right)$, then in order to complement this there appeared the $\mathrm{Vx}$ here represented by $-k$, which thus first indicated reference to indefinite object, then to no object at all. We discussed the problems of this conception in 6.4.

7.2.2. The hypothesis that we shall put forward now is, in a certain sense, the exact opposite of the one above. Namely:

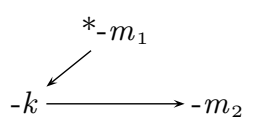

That is, we claim, that the original function represented in the chart by $-k$, did not emerge in relation to the objective ending but in relation to the original, undifferentiated $\mathrm{Vx}$; in other words, that is what it came to stand in contrast to, and the originally only suffix $\left({ }^{*}-m_{1}\right)$ was reanalysed as a suffix indicating definite object $\left(-m_{2}\right)$ only in relation to this other suffix (as non- $k$ ).

Our claim that $-k$ differentiated vis-à-vis ${ }^{*}{ }_{-} m_{1}$ involves the assumption that this process originally had nothing to do with the presence vs. absence of an object, and even the transitive or intransitive nature of the verb was irrelevant. Actually we are convinced that the suffix $-k$ appeared among intransitive verbs - to formally express the semantic content of mediality in the process of the emergence of a separate verbal paradigm type.

7.2.3. Let us then explain what we mean by mediality. The term middle voice is traditionally used in relation to actions (more precisely: events, or even states described by verbs) where the event described by the verb does not transcend the semantic limits of the grammatical subject, i.e., where the subject acts or behaves not with a goal outside itself but for, on, with, in relation to etc. itself (whether actually or habitually), or something happens to the subject, it enters a state without this being the result of some action on anyone else's part. In terms of mediality in 
the broadest sense it is immaterial whether the subject is semantically agent or patient. The middle verbs ugrik 'jump', fut 'run', fordul 'turn (intr)', mosakodik 'wash oneself' have subjects that are agents acting at will, but the similarly middle verbs szédül 'feel dizzy', elájul 'faint', él 'live', van 'is' have subjects that are patients, affected by the event. Inanimate entities are always patients (forr 'boil', lebeg 'float', fénylik 'shine' etc.). Verbs denoting involuntary actions and states can be interpreted as standing between agent and patient: köhög 'cough', fázik 'feel/be cold', fél 'be frightened', örül 'be happy' etc., though we think their subject can be regarded rather as patient in spite of the fact that the subject is acting. Similar boundary cases are represented by verbs denoting habitual actions (which thus turn into properties), occupations; this class includes verbs generalised from transitives as well (házal 'sell door-to-door', vadászik 'hunt', fordit 'translate' in the sense of translating for a living). All these are middle verbs/verb forms. The examples will have made it clear that we also assign verbs here whose subject acts at will and on a goal but the goal is identical to the subject (öltözködik 'dress oneself'). The same stands for events affecting inanimate entities as subjects, where of course one cannot speak of the activity of the subject (ömlik 'pour (intr)', becsukódik 'shut (intr)'). By contrast, real passive verb forms (öntetik 'is poured', becsukatik 'is closed') cannot be regarded as middle in spite of the patient subject, because the events that happen to the grammatical subject have a semantically clearly distinct "subject", in other words: the agent of the event and the grammatical subject are sharply differentiated. It must, however, be borne in mind that not only intransitive verbs can be middle; but more on this will be said later.

The representation of mediality is a motivating force that often appears to be at work in the nominative languages. ${ }^{46}$ It is enough to think of the variety of functions assumed in Romance by the Latin reflexive

\footnotetext{
${ }^{46}$ I have argued elsewhere (Havas 2003, 33ff) that this ultimately goes back to an ancestral principle, which is preserved in an altered form in nominative structures. The essence of this principle is that when the earlier organising principle of sentence structure, the agent-patient distinction is replaced by transitivity, and the nominative subject appears to function as a prototypical agent, those subjects that are patients, contrary to the new majority pattern, come to be marked through medialisation. (Of course we do not assume any kind of teleology languages have neither nostalgia, nor goals, language change only has causes what happens in such cases is the analogical extension of existing middle verb forms.) Acceptance of this hypothesis is independent of the argument in the present paper.
} 
pronoun. The outcomes should, in theory, be reflexive verb forms, but the semantic range is, in fact, much larger. French, for instance, abounds in verbs accompanied by the particle se whose meanings cannot be interpreted as actually reflexive in spite of the corresponding transitive forms without the pronoun: se fâcher 'be/get angry' (not 'anger oneself'), s'endormir 'fall asleep' (not 'lull oneself to sleep'), se battre 'fight' (not 'beat oneself') etc., in some cases the form without se has (nearly or actually) gone out of use, as in s'efforcer 'to make efforts'; and what sort of reflexivity is represented by la tour Eiffel se voit de loin 'the Eiffel Tower can be seen from afar'? This phenomenon is, of course, much older, the reflex of the same pronoun has led to very similar outcome in all the Germanic and Slavonic languages (German sich freuen, Russian радоваться 'be happy' and their counterparts), but examples could be given from nearly any of the Indo-European languages. Nevertheless it would be an erroneous conclusion that this is an ancestral inheritance: this development happened again and again in the individual languages, which is evidenced by the fact that while in Romance and Germanic the "reflexive" particle behaves like a personal pronoun - i.e., it distinguishes person and number, partly coinciding with the accusative of the corresponding personal pronouns: je me fâche, tu te fâches..., ich freue mich, du freust dich...; but witness il se fâche (and not le), er freut sich (and not ihn) - in the Slavonic languages, on the other hand, the item in question (e.g., Russian - $c$ g) extended to all persons. If all these forms are to be interpreted in a semantically unitary fashion (and this is how they were interpreted in the language when they assumed a coherent form), the general meaning has to be that the action is semantically middle.

In Hungarian this tendency is discernible especially in the history of the $i k$-verbs. Wherever the $-i k$ suffix comes form, it has always behaved as a middle derivational morpheme. ${ }^{47}$ In suffix clusters its mean-

${ }^{47}$ Here we only note, though it would deserve a study on its own, that we find the derivation of $-i k$ from the $3 \mathrm{pl}$ ending of the objective conjugation, which has become the orthodoxy in Hungarian historical grammar with Mészöly (1941), totally unacceptable. But supposing that it was true, even the textbook example törik 'break' is not passive in meaning, as such a reanalysis would imply (namely if its subject had been an original object), but middle instead: 'breaking is happening to it; it comes (by itself) to a state of being broken' (let us think of the actual meaning of the sentence $a z$ ág letört 'the bough broke'). If the sentence $a z$ ágat törik 'they break the bough' can be passivised at all in Hungarian, the result is not az ág törik 'the bough breaks' but az ág töretik 'the bough is (being) broken'. Let us note again that törik 'breaks (intr)' is not a passive but a middle 
ing can, of course, narrow down to something more particular: -kodik is mostly reflexive, but often refers to habitual behaviour or occupation, - odik refers to entering a state, -sodik to the acquisition of a characteristic as a result of an event, -ászik to action carried out habitually or as an occupation etc., but the element - $i k$ is still the exponent of the semantic feature of mediality. In the pristine $i k$-verbs its middle meaning is obvious: bújik 'hide', mászik 'crawl', ugrik 'jump', nyúlik 'stretch' etc. (doing something to oneself), alszik 'sleep', csuklik 'hiccup', ellik 'give birth', okádik 'vomit' etc. (doing something involuntarily, or rather undergoing it), fürdik 'bath', mosdik 'wash oneself', öltözik 'dress oneself' (transitive action directed towards oneself), ázik 'soak', kopik 'thin', esik 'fall', válik 'separate' (apparent action is actually undergone), illik 'is proper', kéklik 'is blue', hallik 'is heard', folyik 'flow' etc. (in fact, not an action but a characteristic), eszik 'eat', iszik 'drink', játszik 'play' etc. (originally occupying oneself with doing something). For most of these verbs it seems plausible to assume that the suffix $-i k$ agglutinated in itself to a relative stem (in other cases it may have attached to the verb analogically in suffix clusters, but the original cases, which served as the basis of analogy, obviously acquired suffix clusters only later and may even have had endings that could become autonomous, i.e., the addition of -ik can be regarded in principle as a separate issue). Some of these verbs are not only assumed but also attested by documents to have been non- $i k$-verbs: foly 'flow', hazud 'lie', esz 'eat'. ${ }^{48}$ The hundreds of modern Hungarian

verb form and we are convinced that it never was otherwise. Let us also note in passing that the ordinal suffix -ik (második 'second' etc.) is of unknown origin, but it is clear that - unless its similarity to the verbal suffix - $i k$ is an accident it clearly cannot be derived from a verbal (actually, objective) suffix; though an original suffix $-i k$, functioning as a "self-identifying" derivational suffix on nouns as well as verbs is not out of question. (In Uralic linguistics the idea has been around that the verbal suffix $-i k$ goes back to the combination of the pronoun $* s i$ and an emphatic suffix $-k k$. If this is correct, the ordinal suffix cannot be related to it, or at most its consonant can.)

48 The medialising function of $-i k$ in eszik is clearly indicated by the fact that when the verb is used transitively but with a non-third-person object, it does not have the -ik: esz a fene 'I am annoyed', lit. 'disease is eating me', megesz a sárga irigység 'I am yellow with envy', lit. 'yellow envy is eating me'. What this means is that in 3sg the general vs. definite contrast was carried by the pair of forms esz - eszi, and eszik did not come into being in contrast to eszi but to esz, as a middle verb form with the original meaning 'is occupied with eating'. We are convinced that first it was not transitive (just like játszik 'play'), although intransitivity is not a prerequisite to mediality. The sentence kenyeret eszik 'he is eating bread' is now a transitive phrase, but originally it was only a specification of the verb 
$i k$-verbs that refer to actions involving the use of instruments of sport, music, or indeed any kind of instrument have been created mostly over the past one or one and a half centuries (szánkóz 'slide with sleigh', zongoráz 'play the piano', dohányoz 'smoke cigar(ette)s' were in general use even in the early twentieth century). Some forms fluctuate to this day (vész - veszik 'is lost'). Some verbs are "hypermedialised" in the current colloquial language (látszódik 'is seen'). All these point - as typical examples - to a strong and still productive tendency of medialisation in Hungarian.

7.2.4. We thus assume that the conjugation called general ("subjective") - and we are still talking about the first two persons -, emerged to represent the mediality of the action, event or state denoted by the verb in contrast to the ancestral, undifferentiated Vx-series. ${ }^{49}$ The history of verbal derivation shows that a number of the suffixes that originally attached to the pure verb stem carried the meaning of mediality besides a more specific meaning (frequentative, inchoative, durative etc.). With the suffixes that now function as $\mathrm{Vx} 2 \mathrm{sg}(-l,-s z)$ this is obviously the case: tanul 'learn', ugrál 'jump around', rikácsol 'screech', vádol 'accuse', énekel 'sing' - the traditional explanation assigns to these the labels frequentative, reflexive or momentary, but the common core of these meanings is precisely mediality; and the suffix $-s z$ is not only identical to that found in lesz 'become', tesz 'put', visz 'carry', identified sometimes as present, sometimes as frequentative, but, in all likelihood, also to the $s z$ in -ász/-ész. ${ }^{50}$ This last suffix is a denominal verbal suffix denoting an activity or occupation related to the noun in the stem, i.e., a typically middle meaning. ${ }^{51}$ The $1 \mathrm{sg}$ suffix $-k$ is more of a problem; it is tradi-

eszik, still middle, and it answered the question 'what is he doing' rather than 'what is he doing with the bread?'.

49 The possibility of such a development is underscored among others by some languages in the Balto-Finnic branch of the Uralic family, e.g., Veps, in which there is a contrast between a general and a reflexive-medial conjugation, as well as the history of the Indo-European languages (in Greek, for instance, it is clear that the passive voice, which has an incomplete paradigm, grew out of the middle voice; the original contrast was thus general vs. middle).

50 The long vowel obviously goes back to the stem-final vowel or a further derivational suffix, which coagulated with the stem, thus the $-s z$ is diachronically separate.

${ }^{51}$ In 3 sg the semantic feature of mediality was later reinforced through the addition of the suffix $-i k$, which completed the process of turning these forms into verbs (halászik 'he fishes'); the form without -ik lost its nomen-verbum character and 
tionally identified - in want of a better explanation - with a deverbal nominal suffix (rejtek 'hiding place', hajlok hajlék 'dwelling place'), ${ }^{52}$ but this is a rather laboured solution given that a $1 \mathrm{sg}$ verb form can hardly derive from a nominal function. ${ }^{53}$ The idea that the form may go back to an endearing, diminutive formation applied by the speaker to himself ${ }^{54}$ - apart from doubts of a different nature - does not answer the question why this formative only occurs in this conjugation. We assume, in contrast to all previous explanations, that $-k$ was originally a medial suffix. ${ }^{55}$

No matter how we explain the origin of the suffixes $-k,-s z,-l,-i k$, it still remains a problem why they turned into Vx-es in just those persons in which they did, since nothing predisposed them to it. We have no explanation ourselves; at any rate, we do not have an account that would be superior to those unconvincing ones proposed before us. Anyhow, these endings pose three questions that need answering: what they derive from, why they attached to the verb and why they denote the specific persons they denote. The first and last of these is clearly language-specific. Typologically, however, it is the second question that proves most interesting, since this is where cross-linguistic tendencies can be uncovered. If we see that an object-dependent conjugation came into being in several

was fixed as a noun (halász 'fisher'). Similar "oversuffixation" may have taken place with alszik 'sleep', fekszik 'lie', nyugszik 'rest', where again the middle meaning of the $s z$ is discernible.

${ }^{52}$ E.g., Berrár $(1967,418)$.

${ }^{53}$ Rédei derives all the three Vx-es from participial suffixes. This is certainly a more plausible solution than the assumption that they were nominal suffixes. In the latter case the finite verb would go back to a nominal predicate, but this would necessarily involve the assumption - with an eye to the differentiation from the ancient $\mathrm{Vx}$-es, which derive from pronouns - that for some reason after a long period of distinct verbal predicates they started using nominal sentences instead. The same problem does not arise with participles, since they undeniably share the verbal nature, and a sentence with a participial predicate can be taken as a verbal as well as a nominal sentence. (This is exactly why certain participial predicate forms are incorporated into the conjugation system.) Furthermore, a participial suffix can be semantically middle, e.g., attributing a typical feature or a habitual occupation to the subject (elsôszülött 'first-born', halandó 'mortal', iró 'writer', jegyző 'notary').

${ }^{54}$ Nyíri $(1974,144)$, based on others; the hypothesis rests on the analogy of Vogul.

${ }^{55}$ Since we completely refuse the derivation of $-i k$ from $3 \mathrm{pl}$ and assume that $-i k$ is originally also a medial suffix, we venture to claim (though it may be far-fetched) that $1 \mathrm{sg}-k$ and $3 \mathrm{sg}-i k$ may be etymologically related. 
languages, and that in some of them the non-object-oriented conjugation developed in a fashion similar to that seen in Hungarian, then it would be erroneous to try and seek individual and particular explanations for each of them, including Hungarian. It is much more likely that the driving force behind the process is a general diachronic tendency of medialisation.

Given all this, we suggest the following modification in the scheme of development presented as (8) in $\mathbf{6 . 4}$ (and then questioned):

\begin{tabular}{|c|c|c|c|}
\hline & intransitive verb & $\begin{array}{l}\text { transitive verb }+ \\
\text { indefinite object }\end{array}$ & $\begin{array}{l}\text { transitive verb }+ \\
\text { definite object }\end{array}$ \\
\hline initial stage & futom & adom & adom \\
\hline intermediate stage & futok & adom & adom \\
\hline final stage & futok & adok & adom \\
\hline
\end{tabular}

That is, we assume that in the intermediate stage an (intransitive) middle conjugation appeared, which was at that time crucially contrasted to a non-middle conjugation, although the above chart implies that the opposite was not non-mediality but transitivity. But if the opposition had been based on transitivity, that should have led to extensive objectdependence, which is contradicted by the eventual outcome.

The spreading of the middle conjugation to transitive verbs - i.e., the formation of what we now call the indefinite conjugation of transitive verbs - can be understood if we appreciate that certain types of the use of transitive verbs were not defined by their transitivity in the first place but by the mediality of their meanings. The essential semantic difference between a ló megeszi a zabot 'the horse eats the oats' and a ló zabot eszik 'the horse eats oats' is not in the definiteness or indefiniteness of the object but in the semantic intention that prompts the selection of one or the other. While the structure with the definite object tells what the horse is doing to the oats, the sentence with the indefinitely conjugated verb is a statement purely about the horse, and in ordinary use it would not answer the question what the horse is doing here and now but what it usually and typically does. (In its most natural use the sentence a ló zabot eszik is equivalent in meaning to 'horses are oat-eating animals'.) ${ }^{56}$ But even in its "here-and-now" interpretation the sentence is not a statement about oats but an explication of the middle meaning 'the

${ }^{56}$ This is especially clear in the negative: a ló nem eszik húst 'the horse does not eat meat', i.e., 'horses do not eat meat' is obviously not a statement about what a horse is doing to the meat but answers the question what sort of an animal a horse is just like e.g., the sentence horses are mammals. 
horse is eating': 'the horse is busy eating oats, is occupied with eating oats'. From the point of view of semantic intentions what is syntactically the object of the verb is more of an adverb of circumstance: gyorsan eszik 'he eats fast' and kenyeret eszik 'he eats bread' are closer to each other than the latter is to eszi a kenyeret 'he is eating the bread'. It is precisely these forms with syntactic object but with middle meaning that bridge the gap between intransitive middle verbs and transitive verbs with indefinite object; so much so that it would probably make more sense to talk about the simultaneous emergence of intransitive middle forms and middle forms of transitive verbs with indefinite object rather than the spread of the former onto the latter. ${ }^{57}$

Thus what is now called indefinite or general conjugation was a middle conjugation in the beginning. Later the original middle formation analogically spread to those cases where the content to be expressed was not actually middle but the object of the verb was not salient. Such analogical spread could easily take place between structures like kenyeret sütök 'I bake bread' and jó kenyeret sütök 'I bake good bread' or öt kenyeret sütök 'I bake five loaves' since the respective adjectival and numeral attribute may have seemed more of an explication of the original event - even though it is only the first of these sentences that is middle, i.e., which answers the question what the subject is in the process or habit of doing. ${ }^{58}$ On the other hand, this analogical extension was obviously facilitated by the possibility of a double interpretation of the forms with ancestral Vx-es, more precisely by an analogical reanalysis in that paradigm as well. This is because a verb form accompanied by a definite object is by its very nature non-middle and from here it is only a small (though logically unjustified) step to reverse the equation: non-middle forms are characterised primarily by having definite objects. Thus in the case of transitive verbs the middle vs. non-middle bifurcation was reanalysed as an indefinite object vs. definite object bifurcation. So the emergence of the non-middle indefinite-object conjugation and through this the emergence of the current general conjugation on the one hand,

\footnotetext{
${ }^{57}$ It is unlikely that there would have been a time when eszik 'he eats' or gyorsan eszik 'he eats fast' had the $-i k$ suffix but the indefinite transitive forms lacked it, e.g., kenyeret esz 'he eats bread'. It seems more likely that the -ik appeared simultaneously and for the same reason on the form that contrasted with eszi, viz. to reinforce its middle meaning.

${ }^{58}$ It is well to point out here that the sentence jó kenyeret sütök 'I bake good bread' still has a reading that can be regarded as middle, viz. 'I am a good baker'.
} 
and the reinterpretation of the conjugation with the ancestral Vx-es as a conjugation used with definite objects on the other, were two parallel developments, whose chief cause was on the one side the encroachment of the middle conjugation onto a semantically non-middle domain - when the object was used as an adverb of circumstance - , on the other side the secondary cause (partly acting in tandem with the former) was that the feature of non-mediality lost ground to that of definiteness.

7.3. Let us now briefly return to the developments in the third person, which we have been able to trace back on its own right as far as a putatively extensive, i.e., intransitive vs. transitive, contrast. We noted previously that the distinction in $3 \mathrm{sg}$, which appeared much earlier, had the possibility of serving as the functional background for the bifurcation of the suffixation in the first two persons. But here eventually we have to assume a cause-and-effect relation working in the opposite direction. Since intensive object-dependence, the contrast between a general and a definite conjugation, diachronically presupposes the feature of mediality, it must have appeared initially in the first two persons (we can leave $i k$-verbs out of consideration, because $-i k$ as a personal ending was not generalised for the third person). Thus in the third person the last step (replacing extensive with intensive object-dependence) was taken, in all likelihood, on the analogy of the development of such a contrast in the first and second persons, when this latter had been completed. The completely generalised intensive object-dependent conjugation system of Modern Hungarian, i.e., the contrast between verbs accompanied by a definite object vs. everything else, ultimately results from this twopronged interference. ${ }^{59}$

7.4. With respect to its history and semantic content we can say with certainty that the motivation and the driving force for the emergence of the Hungarian objective (definite) conjugation are in fact to be foundat least in the first two persons - on the other side, in the process of the formation of the indefinite conjugation. To put it bluntly (though

\footnotetext{
${ }^{59}$ It has long been observed that in the early documents of Hungarian the distinction between the two types of conjugation is not made along exactly the same lines as in Modern Hungarian (see e.g., Gergely 2001). This can perhaps be interpreted not as a sort of rule-infringement or gratuitous commingling of forms but as an earlier stage of the generalisation of the middle conjugation, or a vacillation of the object-dependent conjugation between an earlier (middle vs. non-middle) and a later (general vs. definite transitive) principle of contrast.
} 
loosely): it is not the objective but the subjective conjugation that actually emerged. What is now called general conjugation separated from the homogeneous ancestral conjugation and gradually assumed a form of its own; the original conjugation, which remained "unchanged", was reinterpreted as a definite transitive conjugation because of, and in contrast to, the other.

7.4.1. An obvious objection that could be made at this point is that our hypothesis only applies to the singular, because in the plural the pattern is just the opposite: the indefinite conjugation preserved the original Vx-es and they are not found in the definite conjugation. We find this widespread opinion erroneous. First of all it only applies to 1pl; in the third person neither the definite, nor the indefinite forms contain the ancient subject-marking Vx (látnak ${ }^{60}$ 'they see', látják 'they see it'), whereas in the second person both forms contain it (láttok 'you see', látjátok 'you see it'). Anyhow, in all the three persons of the plural the developments are internal to Hungarian in that their (innovative?) immediate stem is the $3 \mathrm{sg}$ form of the definite paradigm (*látjá-). ${ }^{61}$ This is due to the fact that, as we have already said, the Vx of the third person - as opposed to that of the first two persons - is an element that marks the object and it was in that capacity that it analogically intruded on the first two persons. So the $3 \mathrm{pl}$ form is simply a plural-marked $3 \mathrm{sg}$, and the objective $2 \mathrm{pl}$ is a subjective form of the same person plus a formative referring to the object (here $-j a ́$ - is actually an objective infix). ${ }^{62}$ We are left with the $1 \mathrm{pl}$ form, where the formative ${ }^{*}-m$ only remains now in the indefinite conjugation (-unk vs. $-j u k$, where - unk $<$ stem-final $u+m \bullet+k$ ). The $-j$-found in the objective form is clearly the same as that of $3 \mathrm{sg}$ (and the infix of $2 \mathrm{pl}$ and $3 \mathrm{pl}$ ), at most with the loss of a vowel (if there ever was

${ }^{60}$ The $-n$ - in -nak can be diachronically analysed as a third person subject-marking element, but it is not an ancient Vx (it does not go back to a PP); otherwise -nak mostly contrasts even today with a 3 sg zero morpheme, so - $n$ - cannot be descriptively analysed as a separate entity (in other words, $-n a k$ is synchronically unanalysable).

${ }^{61}$ Similar developments are seen in the case of the Px-es: kalapjaink, kalapjaitok, kalapjaik 'our/your/their hats' on the analogy of kalapja 'his hat' instead of kalapink, kalapitok, kalapik.

${ }^{62} \mathrm{We}$ are left in the dark as regards whether there existed other ancient plural forms before the intrusion of the -já- element in the undifferentiated $>$ objective conjugation (were there ancient plural forms at all?), thus the medialisation hypothesis is neither confirmed nor disconfirmed by these formations. 
one) before the $-u-$; this latter can only have appeared in this form on the analogy of the general suffix -unk. Given all this one would expect, parallel to the $2 \mathrm{pl}$, a látu-mu-k $\leftrightarrow{ }^{*}$ lát-j-unk contrast in $1 \mathrm{pl}$. And indeed it seems logical that the Pre-Hungarian stage should have included the forms ${ }^{*} l a ́ t u-m u-k \leftrightarrow$ látu-ju-mu-k. ${ }^{63}$ First, in the definite form the presence of the $-j \bullet$ - open syllable made it possible for the preceding (stemfinal) vowel to syncopate. Secondly, and more importantly, when in the indefinite form the vowel before the plural marker was dropped (*látu$m u-k>{ }^{*} l a ́ t u-m-k>$ látu-n-k), the definite form with its two $u$-s, which were independent of the stem and thus felt to belong to the ending, and especially with the position of the second before the plural marker, was by then so removed from the indefinite that at least one of its syllables could be freely dropped. It must be added that the form with $u$ only characterised the $1 \mathrm{pl}$, thus ultimately it may have been interpreted as the exponent of the first person. Naturally the same stands for the palatal $1 \mathrm{pl}$ formations. All this then led to the syncopation of the newly redundant syllable -mu-/-mü-, and this is how the current forms látjuk/ vetjük (láttyuk/vettyük) 'we see it/we cast it' came into being. ${ }^{64}$ In sum, the cross-classifying distribution of the ancestral Vx-es in the singular and the plural is only an illusion and, on top of all that, since the plural forms are diachronically based on the hypersuffixation of an earlier 3sg form with a definite objective meaning, they have nothing to tell us about the original formation of the two conjugations.

7.4.2. If we look at the current coincidences between the definite and the general conjugations, what we see is that it is always the original, not the innovative, suffix that turns up unexpectedly. Thus the diachronic question that we must ask is obviously why the change, i.e., the medialisation did not take place in the given formation.

7.4.2.1. There are obvious cases, like the past indefinite 1sg (kértem 'I asked', vártam 'I waited', where the expected alternation between $m \sim$

${ }^{63}$ The vowel following the $-j$ - may have assimilated to $u$ under the influence of the two adjacent syllables even if it was originally different.

${ }^{64}$ Consideration of the other moods and tenses does not add anything to this conception of the changes. In the case of látánk 'we saw' and látnánk 'we would see' the two conjugations are not distinguished, in the case of látnók (<*látno-uk?) 'we would see it', láttuk 'we saw it' and lássuk 'let us see it' the analogy of the declarative may have been at work (or, in the imperative, the same process may have taken place as in the declarative present objective form - but clearly earlier because the assimilation of the $-j$ - is older there). 
$k$ would have led to homophony with the $3 \mathrm{pl}$ form of the same paradigm (kértek 'they asked', vártak 'they waited'). ${ }^{65}$

7.4.2.2. The pristine $i k$-verbs present a more difficult case. The "unwarranted" appearance of $-m$ in the indefinite conjugation is conspicuous even to non-specialist native speakers. Furthermore, no immediately convincing syntactic or morphological reason is found here. Nevertheless, we believe that the medialisation hypothesis does offer a sort of explanation: the pristine $i k$-verbs were so conspicuously middle semantically that stressing this through resuffixation proved unnecessary. We are aware, of course, that this explanation, which draws on the original and persevering presence of the middle meaning in 1sg but the need to stress the same meaning in the other two persons (since that is how we explained the replacement of the ancestral Vx-es) is not without problems. Not even if we add that semantically the first person singular is the most "self-identical" ("most middle") subject, and against $-k$ there was the menacing possibility of a partial coincidence with the $3 \mathrm{sg}-i k$ ending (though this did not seem to prevent the later intrusion of $-k$ into the paradigm). We cannot say more about this at present, and, to the best of our knowledge, nobody else can. Let us conclude that what we see in the $1 \mathrm{sg}$ is not the "objective" conjugation of the $i k$-verbs but a defect in the formation of the middle conjugation. The $-m$ among the $i k$-verbs is the perseverance of the original, undifferentiated $\mathrm{Vx}$, whereas the objective $-m$ is the later grammaticalisation of the same ancestral $\mathrm{Vx} .{ }^{66}$

7.5. Finally - if we wish to give a full account of the object-oriented conjugation in Hungarian - we have to discuss the formation of -lak/-lek. Materially the $-k$ in it presents no problem: it is the same as the general

${ }^{65}$ The homophonic clash between $1 \mathrm{sg}$ and $3 \mathrm{pl}$ in nézék 'I saw/they saw it' and néznék 'I would see/they would see it' is not within the same paradigm, thus cannot lead to confusion in particular utterances (the problem does not even arise with láték 'I saw' and látnék 'I would see', though it is possible that the appearance of the palatal vowel in the suffix is related to the tendency to differentiate from the definite $\mathrm{Pl} 3$ form); the same stands for the older and the innovative inflected forms of the $i k$-verbs: the $1 \mathrm{sg}$ vs. $3 \mathrm{sg}$ interpretations of $e n$ nék 'I/he would eat' belong to two different paradigms (enném, ennél, ennék vs. ennék, ennél, enne).

${ }^{66}$ Let us note here that the current forms játszok 'I play', eszek 'I eat', alszok 'I sleep' are not medialisations but result from the simple formal analogy with the non- $i k$-verbs. In this way the possibility to distinguish between the two conjugations emerges here as well (kenyeret eszek 'I eat bread' vs. megeszem a kenyeret 'I eat the bread'), but this is clearly a consequence and not a motivation. 
1 sg ending. As for the $-l-$, there are two possible explanations. One is that it is etymologically identical to the $2 \mathrm{sg}-l$. If it indeed is, it has to be an object-marking element, and it is coherent with the overall pattern that it precedes the subject-marking element (this is what we see in the plural of the objective conjugation). But this explanation faces two serious obstacles. One is that the stages of agglutination - namely the first, when there was only an - $l$ - are very difficult to argue for (some hold that there never was a *kérel form as the antecedent of *kérelek $>$ kérlek 'I ask you'). The other is that the - $l$ - should be regarded as an object-marker, which is unparalleled (since it always marks the subject in the middleintransitive series). The other attempt ${ }^{67}$ at an explanation assumes that the $-l$ - is a transitivising suffix, the variants kérek and *kérelek may have existed side by side but both belonged to the general conjugation, and only a bifurcation of their contexts (kérek valamit 'I ask (for) something' vs. *kérelek téged/titeket 'I ask you') led to the current transitive, secondperson-oriented meaning of the -lak/-lek suffix. The problem with this explanation is that that there is no evidence whatsoever for such a bifurcation of contexts (all the more so in view of the fact that there is no trace of anything similar in the case $1 \mathrm{pl}$ subject: kérünk - and not *kérlünk - téged/titeket 'we ask you'), and thus the explanation really presupposes what it tries to account for. The medialisation hypothesis is of no use at this point either, because the object cannot be regarded as indefinite, let alone irrelevant, as a mere adverb of circumstance. The origin of -lak/-lek is still not a settled question (especially with respect to the why, rather than the what or the how).

8. Summarily we can say the following about the development of objectdependent conjugation in Hungarian.

8.1. The current system, typified by a contrast between a general and a definite conjugation, was first formed in the singular, goes back ultimately to two different sources, and developed along two logically different paths.

8.1.1. In the third person, the verb was originally unsuffixed both in transitive and intransitive use, but if a transitive verb was not immediately followed by a nominal object, the latter could be replaced by a deictically, anaphorically or cataphorically used third person pronoun. Later the explicit nominal object could accompany this structure, first as

$$
{ }^{67} \text { Nyíri (1974). }
$$


an explicatory apposition. This syntagmatic structure can, in this form, be traced back to Proto-Uralic. In a later, undefined stage - perhaps already in Proto-Ugric, but possibly only as late as in Pre-Hungarianthe syntagmatic boundary between the object pronoun and the nominal object was blurred and a unitary object syntagm came into being, in which the pronoun ultimately turned into a Vx through agglutination. The contrast that this led to was the basis of an extensive object-dependent system (i.e., an intrasitive $\leftrightarrow$ transitive distinction).

8.1.2. In the first and second persons, the verb was suffixed in all tenses and moods in the same way in Pre-Hungarian with the Vx-es going back to ancestral Uralic pronouns. A middle conjugation then emerged as separate from the original uniform conjugation first among intransitive verbs, then among verbs accompanied by an object that functions as an adverb of circumstance, with the help of various middle suffixes (the same happened in a parallel fashion with the $i k$-suffix in the third person), thereby resulting in a middle $\leftrightarrow$ non-middle contrast. Later mediality was extended to those non-middle structures where the object was semantically not salient. In this way a distinction developed between conjugations used with no salient objects on the one hand and with salient, semantically determinate objects on the other, which has developed eventually into the current general $\leftrightarrow$ definite contrast (intensive object-dependence).

8.2. It is possible that the earlier (extensive) object-dependence in the third person gave a sort of structural support for the reanalysis of the changes affecting the first two persons. In the third person, however, the intensive type contrast that replaced the earlier intransitive vs. transitive dichotomy reflects the analogy of the developments in the first and second persons. The two systems thus approached to each other and it was in this way that they finally settled on the present state, a contrast between general and definite transitive conjugation, whereby both systems gave up the original principle behind their emergence (mere transitivity in the third person and mediality in the first two).

8.3. Exceptions can be accounted for with reference to a process of medialisation arrested in mid-course, which can be explained in part. A convincing etymology for -lak/-lek is still not in view.

9. From a Uralic point of view, both the developments unique to Hungarian and typological aspects indicate that the roots of an object-dependent conjugation appear to have been present in the proto-language 
only as a potentiality, and only in the third person. As an alternative to verb + object, there existed an originally complex syntagmatic combination (verb + personal pronoun object with accusative function [and form?] + appositive nominal object), which could later develop into an objective conjugation. These syntagms included the pronoun ${ }^{*} s e(m)$, which also goes back to Proto-Uralic. On this structural and material basis in the successive proto-languages of separate branches, or even more in the individual languages, independent but similar developments may have led to the emergence of an object-dependent conjugation through the agglutination of the PP to $\mathrm{Vx}$ in the third person. In the other persons an objective conjugation or some syntagm that could have served as its basis can perhaps be hypothesised but not argued convincingly for Proto-Uralic. The fact that the roots of the objective conjugation are Uralic only in terms of their syntactic basis and only in the third person and that the development of an overall system is later and often confined to individual languages explains why object-dependent conjugation is of different types even in those languages in which it exists. In those Uralic languages which possess no object-dependent conjugation in their current form, it either never existed or its internally developing roots withered away. The presence of $\mathrm{Vx}$-es or elements of Vx-es going back to original Uralic PP-s is general in the family, but this fact - apart from the third person alternatives mentioned above - does not appear to be related to the development of object-dependent conjugation, or if it is, that relation is of a deeper, typological nature (and thus can lead to similar results in various languages independently of their genetic relatedness).

10. From a typological point of view, the organising principle of objectdependent conjugations shows universal tendencies independent of genetic relatedness and areal coherence. ${ }^{68}$ For instance, the fact that in Hungarian the original Vx-es going back to personal pronouns are found in the object-oriented, and not in the non-object-oriented, conjugation, is by no means unique; it is actually an instantiation of a globally dominant, if not universal, tendency. Thus it seems desirable to explain them with reference to motivating forces that are relevant independently of genetic and areal constraints instead of ad hoc and specific events. Only such principles can explain why similar structures and systems develop in

${ }^{68}$ And it also appears to be universally accidental: an object-dependent conjugation may appear in any language at any time, but this is never necessary. 
unrelated languages or why dissimilar structures and systems develop in related languages. The present study is based on the assumption that medialisation, which explains the distribution of original Vx-es on the basis of the separation of the non-object-oriented from the ancestral conjugation, and thus presents the reanalysis as object-oriented of the reflexes of the original forms as the consequence, and not the cause (let alone the goal) of this process, may be such a diachronic linguistic tendency, "independent of time and space".

Deep diachronic typological causes may account also for the universal tendency that the reflexes of the original Vx-es appear as object-marking, and not subject-marking, elements in analytic object-dependent conjugations too, or - which may be even more distantly related to all these considerations - that in certain languages while the (elements of) Vx-es going back to personal pronouns mark the subject, they do so only on transitive verbs. This ancient relation between transitive verbs and their objects, which is a more intimate relation than that between the same verbs and their subjects, and which is highlighted by all these phenomena, goes back, in all likelihood, to pretransitive (and thus prenominative and preergative) sentence structures - but this would lead us too far.

Let us also note that the intensive partiality of object-dependent conjugation also shows universal tendencies. For instance - as one would perhaps expect given what has been said above - it is generally true that where object-dependent conjugation exists only in one person within a paradigm, that person is always the third, never the first or the second. Furthermore, a number of languages point to the fact - which we cannot explain - that where object-dependent conjugation exists only in one tense, that tense is always (one of) the past tense(s), never the present or the future. A hypothesis can perhaps be formed that if object-dependent conjugation emerges in a language, it is most likely to do so in the third person of the past. Hungarian indicates that this tendency is not without exception, but that it may nevertheless be relevant to indigenous systems has been proved recently - through diachronic analysis, without reference to this universalist hypothesis - in the diachronic derivation of the objective conjugation of Mordvin, once again a Finno-Ugric language. ${ }^{69}$

${ }^{69}$ Keresztes (1999, esp. 106).

Acta Linguistica Hungarica 51, 2004 


\section{References}

Abaffy, Erzsébet E. 1991. Az ikes ragozás kialakulása. A határozott és az általános ragozás elkülönülése [The emergence of the $i k$-conjugation. The separation of the definite and the general conjugations]. In: Loránd Benkő-Erzsébet E. AbaffyEndre Rácz (eds): A magyar nyelv történeti nyelvtana. 1. kötet: A korai ómagyar kor és elözményei [A historical grammar of Hungarian. Volume 1: Early Old Hungarian and its antecedents], 125-39. Akadémiai Kiadó, Budapest.

Berrár, Jolán 1957. Magyar történeti mondattan [Hungarian historical syntax]. Tankönyvkiadó, Budapest.

Berrár, Jolán 1967. Mondattörténet [Historical syntax]. In: Géza Bárczi-Loránd Benkő - Jolán Berrár: A magyar nyelv története [The history of the Hungarian language], 389-486. Tankönyvkiadó, Budapest.

Budenz, József 1890-1892. Az ugor nyelvek szóragozása I. Igeragozás [The inflectional morphology of Ugric languages I. Verbs]. In: Nyelvtudományi Közlemények 22 : 417-40.

Büky, László - Tamás Forgács (eds) 2001. A nyelvtörténeti kutatások újabb eredményei II. Magyar és finnugor alaktan [Recent developments in historical linguistics II. Hungarian and Finno-Ugric morphology]. JATE, Szeged.

Comrie, Bernard 1980. Inverse verb forms in Siberia: evidence from Chukchee, Koryak and Kamchadal. In: Folia Linguistica Historica 1:61-74.

Csúcs, Sándor 2001. Tárgyas ragozás az uráli nyelvekben. [Objective conjugation in Uralic]. In: Büky-Forgács (2001, 29-36).

É. Kiss, Katalin 2003. A szibériai kapcsolat, avagy miért nem tárgyasan ragozzuk az igét 1 . és 2 . személyü tárgy esetén [The Siberian connection or why verbs are not objective with a first and second person object]. In: Magyar Nyelvjárások 61: $321-6$.

Feoktistov, Aleksandr P. 1966. Эрзянский язык. In: Vasiliy I. Litkin-Klara Y. Maytinskaya (eds): Языки народов СССР, Том третий, Финно-угорские и самодийские языки, 177-98. Наука, Москва.

Gergely, Piroska B. 2001. Az általános és határozott igeragozás keveredése a XVI.-XIX. századi Erdély beszélt nyelvében. [The vacillation between general and definite verbal conjugation in the colloquial language of 16-18th century Transylvania]. In: Büky-Forgács (2001, 19-28).

Gombocz, Zoltán 1930. Über die Haupttypen der ungarischen Verbalformen. In: Ungarische Jahrbücher 10:1-15.

Hajdú, Péter 1966. Bevezetés az uráli nyelvtudományba [Introduction to Uralic linguistics]. Tankönyvkiadó, Budapest.

Hajdú, Péter 1985. Уральские языки и народы. Прогресс, Москва.

Havas, Ferenc 2003. A tárgy tárgyában. Mondattipológiai fontolgatások [On the object. Sentence-typological considerations]. In: Oszkó-Sipos (2003, 7-44).

Honti, László 1996. Az uráli nyelvek tárgyas ragozású igealakjainak történeti elözményéről [On the history of objective verb forms in Uralic languages]. In: András Bereczki - László Klima (eds): Ünnepi könyv Domokos Péter tiszteletére 
[Festschrift for Péter Domokos.] (Urálisztikai tanulmányok 7), 127-32. ELTE BTK Finnugor Tanszék, Budapest.

Honti, László 1998/1999. Gondolatok a mordvin tárgyas igeragozás uráli alapnyelvi hátteréröl [On the Uralic background of the Mordvinian objective conjugation]. In: Nyelvtudományi Közlemények 96:106-19.

Hunfalvy, Pál 1862. A személyragok viszonyáról a birtokra és a tárgyra a magyar nyelvben [On the relation between personal endings and possessives and objects]. In: Nyelvtudományi Közlemények 1:434-67.

Juhász, Dezső 1999. A történeti nyelvtan néhány kérdése a nyelvföldrajz szemszögéből [Some questions of historical grammar in view of linguistic geography]. In: László Büky - Tamás Forgács (eds): A nyelvtörténeti kutatások újabb eredményei I. Magyar és finnugor mondattörténet [Recent developments in historical linguistics I. Hungarian and Finno-Ugric historical syntax], 81-90. JATE, Szeged.

Keresztes, László 1999. Development of Mordvin definite conjugation. SUS, Helsinki.

Klemm, Antal 1928-1942. Magyar történeti mondattan [A historical syntax of Hungarian] I. 1928, II. 1940, III. 1942. Pécsi Egyetemi Könyvkiadó és Nyomda, Budapest.

Körtvély, Erika 2003a. A determinált igeragozás használati problémái a tundrai nyenyecben [The use of the determinate conjugation in Tundra Nenets]. In: OszkóSipos (2003, 96-113).

Körtvély, Erika 2003b. A tundrai nyenyec igeragozás [The Tundra Nenets conjugation]. Doctoral dissertation, Szegedi Tudományegyetem, Szeged.

Lommel, Arle R. 1998. An ergative-absolutive distinction in the Hungarian verbal complex. In: LACUS Forum 24:90-99.

Melich, János 1913. A magyar tárgyas igeragozás [The Hungarian objective conjugation]. In: Magyar Nyelv 9:1-14.

Mészöly, Gedeon 1931. A Halotti Beszéd tárgyas elbeszélő múlt alakjai [The objective narrative past forms in the Funeral Speech]. MTA, Budapest.

Mészöly, Gedeon 1941. Az ikes ragozás -ik ragjának eredete [The origin of the -ik suffix in the $i k$-conjugation]. In: Nyelvtudományi Közlemények 51:1-13.

Miyaoka, Ahito 1996. Sketch of Central Alaskan Yupik, an Eskimoan language. In: Ives Goddard (ed.): Handbook of North American Indians, Volume 17: Languages, 325-35. Smithsonian Institution, Washington.

Nyíri, Antal 1974. A magyar igeragozás története [The history of the Hungarian verbal conjugation]. In: Magyar Nyelv 69:140-58.

Osnovi 1974. Основы финно-угорского языкознания (Вопросы происхождения и развития финно-угорских языков). Наука, Москва.

Oszkó, Beátrix - Mária Sipos (eds) 2003. Budapesti Uráli Múhely III. MTA Nyelvtudományi Intézet, Budapest.

Papp, István 1942. Mi a szó funkciója? [What is the function of the word?]. In: Magyar Nyelv $38: 272-6$.

Papp, István 1968. Unkarin kielen historia. SKS, Helsinki.

Rédei, Károly 1962. A tárgyas igeragozás kialakulása [The development of the objective conjugation]. In: Magyar Nyelv 58:421-35.

Acta Linguistica Hungarica 51, 2004 
Rédei, Károly 1989. A finnugor igeragozásról, különös tekintettel a magyar igei személyragok eredetére [On Finno-Ugric verbal conjugation with respect to the origin of the Hungarian personal endings]. In: Nyelvtudományi Közlemények 90:14360 .

Thomsen, Vilhelm 1912. A magyar tárgyas ragozásról néhány megjegyzés [Remarks on the Hungarian objective conjugation]. In: Nyelvtudományi Közlemények 41 : $26-9$.

Wacha, Balázs 1974. Az ige és a tárgy kapcsolata a magyarban [The relation between verb and object in Hungarian]. In: Nyelvtudományi Közlemények 76:157-81.

Yaziki mira... 1997. Язики мира. Палеоазиатские языки. Индрик, Москва.

Yaziki mira... 1999. Языки мира. Иранские языки II. Северо-западные иранские языки. Индрик, Москва.

Address of the author: Ferenc Havas

Department of Finno-Ugric Studies

Eötvös Loránd University

Pf. 107

H-1364 Budapest

fhavas@ludens.elte.hu 